\title{
O livro II de O capital e o Direito: um debate com Pachukanis
}

\author{
Vitor Bartoletti Sartori*
}

\begin{abstract}
Resumo: contrário do que se dá usualmente ao tratar do Direito em Marx, trataremos do livro II de $O$ capital. Em primeiro lugar, traremos à tona sua especificidade em relação ao livro I e III da obra magna de Marx. Posteriormente, ao ter em conta a relação entre reprodução e acumulação de capital, analisaremos a posição do Direito nesta obra para, então, tratar de seu aspecto dúplice, que passa pela correlação entre o capital produtivo e o capital improdutivo, ao mesmo tempo em que expressa contradições importantes no sistema de apropriação capitalista.
\end{abstract}

Palavras-chave: Marx, O capital, Direito, Livro II, capital produtivo

\section{The Book II of Capital and tha Law: debate with Pachukanis}

\begin{abstract}
Marx's Book II of The capital. First, we will deal with its plane on Marx's masterpiece; than, taking in account the reproduction and the accumulation of capital, Law will be dealt. Finally, we intend to expose the relationship between Law, productive capital and improductive capital. So, we will deal with some contradictions present in capitalist appropriation system.
\end{abstract}

Key-words: Marx, The capital, Book II, productive capital

Submetido em $16 / 03 / 2020$

Aprovado em 30/04/2020

C $\mathrm{O}$ (s) Autor(es). 2018 Acesso Aberto Esta obra está licenciada sob os termos da Licença Citratixe Commons Atribuição-Nä̊Comercial 4.0 Internacional (https://creativecommons.org/licenses/bxi $n \mathcal{B} / 4.0$ /deednothaR), que permite copiar, distribuir e reproduzir em qualquer meio, bem como adaptar, transformar e criar a partir deste material, desde que para fins não comerciais e que você forneça o devido crédito aos autores e a fonte, insira um link para a Licença Greatixe Commons e indique se mudanças foram feitas.

* Professor do departamento de Direito do trabalho e introdução ao Direito da faculdade de Direito da Universidade Federal de Minas Gerais (UFMG). Docente no programa de Pós-graduação em Direito na Universidade Federal de Minas Gerais. Editor da Revista Verinotio e autor de publicações sobre Marx e marxismo, como os livros Lukács e A crítica ontológica ao direito e Ontologia nos extremos: o embate Heidegger-Lukács, uma introdução. 


\section{Introdução}

No âmbito dos estudiosos da obra de Karl Marx voltados ao Direito há uma prevalência do livro I de $O$ capital. Isto se dá, sobretudo, devido à influência decisiva da obra Teoria geral do Direito e o marxismo (2017), de Pachukanis. Em grande parte tomada como uma interpretação autêntica do Direito em Marx e do modo pelo qual o método marxiano se colocaria (Cf. NAVES, 2000, 2014), esta obra deu a tônica do debate sobre marxismo e o Direito ao enfocar a relação entre forma jurídica e forma mercantil (Cf. PACHUKANIS, 2017); esta relação, por sua vez, ficaria clara ao se ter em conta, sobretudo, a ligação entre os capítulos I e II do livro I de $O$ capital, de Marx.

Assim, o enfoque neste livro da obra magna de Marx apareceu praticamente como evidente. E, claro, do ponto de vista do conhecimento da obra marxiana, é também de grande valia a compreensão dele, bem como o estudo da obra pachukaniana. (Cf. SARTORI, 2015) No entanto, para que seja possível um estudo criterioso do corpus teórico de Karl Marx, é preciso que as outras partes da obra do autor alemão sejam estudadas com o mesmo afinco, também no que diz respeito ao Direito. Tendo isto em conta, aqui não discutiremos os acertos ou erros desta interpretação - por assim dizer, clássica - da obra marxiana. Antes, procuraremos trazer à tona algo que ainda não foi realizado com o devido cuidado, um estudo, mesmo que breve, sobre o Direito no livro II de O capital. ${ }^{1}$ Mesmo que os méritos da obra pachukaniana, também em sua leitura de Marx, sejam muitos (Cf. SARTORI, 2015) ${ }^{2}$, sempre que se trata da análise da obra de um autor clássico - ainda mais de um como Marx, que foi reivindicado por tradições bastante diversas - há de se voltar ao próprio texto, e ao modo pelo qual certas temáticas aparecem diferentemente em diversos momentos de sua obra. Ou seja, não negamos a contribuição da tradição pachukaniana - que, de um modo mais ou menos meandrado, prevalece nos estudos marxistas sobre o Direito -; antes, aqui, tentaremos nos voltar a um texto de Marx - o livro II de $O$ capital - que não foi tratado com o mesmo cuidado, seja pelo próprio autor da Teoria geral do Direito e o marxismo, seja por aqueles que a reivindicam e que, de certo modo, no Brasil, vem fazendo escola, sobretudo, devido à influência de Márcio Naves e, mais recentemente, de Alysson Mascaro. ${ }^{3}$

\footnotetext{
${ }^{1}$ Vinícius Casalino, em seu livro Direito e mercadoria (2011), chega a trazer uma crítica a Pachukanis a partir da problemática da reprodução ampliada, presente no livro II de O capital. Porém, seu enfoque não está na obra de Marx, mas sim na de Pachukanis.

${ }^{2}$ Mesmo que talvez seja possível criticar suas teses centrais, de certo modo, como sugere-se em SARTORI, 2019 a e em PAÇO CUNHA, 2014, 2015.

${ }^{3}$ Mascaro aponta sobre a perspectiva que chama de crítica na filosofia do Direito que "esta perspectiva extraída
} 
Não dizemos que seja preciso voltar-se aos textos do próprio Marx - e não tomar Pachukanis como um intérprete rigoroso da obra marxiana - por simples purismo ou por simples gosto pela marxologia. Também não estamos sugerindo que a análise do texto marxiano possa resolver todos os dilemas colocados na sociedade analisada por ele, a capitalista. Trazemos esta questão à tona porque, mesmo que não suficiente para uma tradição como a marxista - na qual os estudos sobre Marx normalmente se colocam -, o estudo cuidadoso de um autor clássico sempre tem uma função essencial. Ser marxista - ou contrário ao marxismo - sem o conhecimento da obra de Marx parece algo, em verdade, um tanto quanto estranho. A compreensão de uma tradição, bem como dos seus caminhos e descaminhos, remete ao pensamento que a funda; ao mesmo tempo não pode ser reduzido a ele. E, por isso também, parece-nos essencial voltar àquele que talvez seja o primeiro passo na análise do marxismo, e, em específico, da relação entre marxismo e Direito, a análise da obra do próprio Karl Marx, aqui, vista ao se trazer à tona o livro II de $O$ capital.

A análise de autores dentro da tradição marxista, seus papéis em suas épocas, suas contribuições e etc. também é considerado por nós de grande relevo. Porém, os limites deste texto não permitem que se extrapole o pensamento do próprio Marx. Continuemos, portanto.

Alguns estudos já foram realizados no Brasil sobre o Direito em Marx. Além do citado Márcio Naves (2000, 2014), que pode ser considerado o principal marxista estudioso do Direito em nosso país, tem-se - também a partir de uma perspectiva pachukaniana - a obra de Alysson Mascaro $(2008$, 2012) e Celso Naoto Kashiura Jr (2009, 2014). Trata-se de autores que, ao trazer à tona a análise do texto marxiano, têm alta dívida com o autor da Teoria geral do Direito e o marxismo. Principalmente no caso de Kashiura e de Naves, há uma influência fortemente althusseriana também. Mas, não obstante a seriedade, o rigor e a dedicação destes autores, há de se perceber que, quando o texto do próprio Marx é trazido à tona, tem-se por essencial o livro I de $O$ capital, e não tanto uma análise sistemática da obra do autor alemão. É preciso apontar também que alguns momentos da obra marxiana (como aqueles anteriores à Ideologia alemã) são tratados de modo bastante rápido já que, para estes autores, a obra marxiana anterior a este período ainda não teria passado pela ruptura epistemológica, que caracterizaria a cientificidade marxiana, sendo marcada por uma concepção confusa e alinhada com certo "humanismo", típico do pensamento burguês. (Cf. ALTHUSSER, 1979, 1999, 2002) Ou seja, em grande parte, tem-se, também a partir de Althusser, a ausência de um estudo detido da obra

do marxismo, cuja leitura mais profunda está em Evguiéni Pachukanis.” (MASCARO, 2018, p. 315). 
de Marx de seu período formativo (Cf. CHASIN, 2009); há, inclusive, sob a influência de Pachukanis, uma ênfase bastante grande em $O$ capital, e, em especial, no livro I desta obra. Trata-se, pois, de autores que certamente prevalecem devido aos seus méritos e clareza. No entanto, no Brasil, há também estudos distintos sobre o Direito em Marx, mesmo que eles sejam, de certo modo, incipientes. E é preciso que se destaque, mesmo rapidamente, e sem pretensão de ser exaustivo, alguns deles. Os autores mencionados acima trazem uma visão geral do Direito em Marx, como já dito, principalmente, tendo como guia a obra pachukaniana.

Porém, a partir de uma análise mais detida do texto do próprio Marx, pode-se destacar estudos mais cuidadosos sobre momentos específicos da obra marxiana.

Nestas pesquisas, em geral, não se tem a posição pachukaniana ou althusseriana como referência, e, principalmente em contato com a tentativa de renascimento do marxismo, proposta por György Lukács (2013), procura-se analisar os meandros do texto marxiano com o maior cuidado possível. Assim, têm-se, por exemplo: 1) sobre o papel do Direito na formação inicial de Marx, Murilo Pereira Leite Neto (2018), que analisa os textos de 1837 a 1842, e Marco Aurélio Palu (2018) que trata da obra marxiana de 1843; 2) sobre o Direito penal em Marx - de 1842 a 1857 - dispõe-se do texto de Nayara Medrado (2018); 3) sobre a relação entre Marx, Morgan e o Direito nos chamados Manuscritos etnológicos, o estudo de Lucas Parreira Álvares (2019) destaca-se. Com uma perspectiva bastante próxima, há o estudo de José Roberto Almeida Sales Jr. (2018) sobre o papel do Direito na Alemanha, mais precisamente, na Nova Gazeta Renana, de $1848 .{ }^{4}$

Poderíamos ainda mencionar estudos (artigos, principalmente) de menos fôlego sobre o tema, no entanto, para que fiquemos nas pesquisas de maior extensão, basta que mencionemos estas. Assim, de certo modo, pode-se dizer que ainda há um longo caminho no que toca a análise do Direito no pensamento do próprio Marx. Neste ponto, também não seremos exaustivos, mas podemos dizer que faltam estudos sobre o Direito nas obras de 1843-1844, como Sobre a questão judaica (mesmo que este texto seja muito citado) e as Glossas marginais; não se tem uma análise detida do debate de Marx com os neohegelianos, que acontece na Sagrada família e na Ideologia alemã e que passa por diversas pontuações do autor sobre o aspecto jurídico. $\mathrm{O}$ posicionamento de Marx contra Proudhon, em A Miséria da filosofia, bem como no livro III de

\footnotetext{
${ }^{4}$ Seria possível citar algumas outras dissertações, como a de Lucas de Almeida Silva, Marx e o movimento do direito nos textos econômicos (1857-1879) (2018); ou a dissertação de Carlos Florêncio de Melo, O lugar dos Manuscritos etnológicos no pensamento de Karl Marx, um embate com Maine (2019); tem-se também, a partir de uma perspectiva distinta, o estudo de Moisés Soares sobre os Grundrisse, Direito e alienação nos Grundrisse de Karl Marx (2011). Como mencionamos, não pretendemos ser exaustivos ao elencar as pesquisas.
} 
O capital, passa também por uma crítica ao Direito; e tal tema ainda não foi tratado com o cuidado que merece. O modo pelo qual Marx traz reivindicações jurídicas no Manifesto, ao mesmo tempo em que também critica o Direito não foi analisado com rigor. Os textos marxianos sobre a França (Luta de classes na França, O 18 Brumário de Luís Bonaparte, bem como Guerra civil na França) ainda não tiveram uma análise sistemática no que toca o Direito e a função deste nas lutas de classes da época. O papel do Direito na Rússia, em comparação com a Índia e com a China foi trazido à tona somente de modo lateral. (Cf. SARTORI, 2017) Não há também um estudo detido sobre o Direito nas Teorias do mais-valor. Poderíamos mencionar diversas lacunas no estudo sobre o tema em Marx. No entanto, basta-nos ter citado estas para que fique claro que o caminho na compreensão da obra marxiana é mais árduo do que, sob a premissa de que Pachukanis é o elo essencial na pesquisa marxista sobre o Direito, supõe-se. Por isso, é preciso ir para além de Pachukanis.

Nota-se também algo bastante interessante: ao mesmo tempo em que há uma centralidade bastante grande do livro I de $O$ capital nos estudos sobre o Direito em Marx, ainda não se tem um estudo detido e sistemático sobre o próprio livro que é central ao debate. Se em outro lugar já foi debatida a interpretação pachukaniana do livro I (Cf. SARTORI, 2019 a), aqui, nós pretendemos algo diferente: a partir daquilo que José Chasin - na esteira da obra de György Lukács (1959) - chamou de análise imanente ${ }^{5}$, procuraremos trazer à tona o modo pelo qual o Direito aparece no livro II. Já havendo também pesquisas (artigos) sobre o Direito no livro III (Cf. SARTORI, 2019 b), é preciso que se dê início a um estudo sobre o Direito no livro II da obra magna de Marx. Assim, o presente texto tem a pretensão de lançar um debate bastante necessário para a compreensão da obra de Marx. Intentamos trazer uma pequena contribuição ao embate também. Mesmo sabendo que este é um passo que não basta por si só, acreditamos que isto pode ser relevante, tanto para que se dê subsídios para os que aderem à tradição marxista quanto àqueles que pretendem conhecê-la melhor.

\footnotetext{
${ }^{5}$ Como diz Chasin: "tal análise, no melhor da tradição reflexiva, encara o texto - a formação ideal - em sua consistência autosignificativa, aí compreendida toda a grade de vetores que o conformam, tanto positivos como negativos: o conjunto de suas afirmações, conexões e suficiências, como as eventuais lacunas e incongruências que o perfaçam. Configuração esta que em si é autônoma em relação aos modos pelos quais é encarada, de frente ou por vieses, iluminada ou obscurecida no movimento de produção do para-nós que é elaborado pelo investigador, já que, no extremo e por absurdo, mesmo se todo o observador fosse incapaz de entender o sentido das coisas e dos textos, os nexos ou significados destes não deixariam, por isso, de existir [...]”. (CHASIN, 2009, p. 26)
} 


\section{O livro II de $O$ capital, a acumulação capitalista e o nível da abstração em que se coloca a análise do Direito em Marx}

O livro II de $O$ capital coloca-se em um nível mais concreto de análise se comparado ao livro I. Enquanto este último trata do processo imediato de produção, em que é produzido o mais-valor, o primeiro trata do processo de circulação, em que o mais-valor pode - ou não - ser realizado. Dizemos que há um maior nível de concretude, não porque aquilo abordado no processo de circulação seja mais "real" que o que se tem no processo imediato de produção, mas porque o tema analisado aproxima-se mais da experiência concreta dos homens da sociedade capitalista. Em verdade, quando Marx trata das figuras que mais se aproximam da imediatez da efetividade, as determinações essenciais da realidade já estão explicitadas em sua exposição anterior; ao mesmo tempo, elas se ocultam na conformação imediata da realidade e as figuras do processo global de produção passam a ser representadas pelos agentes econômicos como se prescindissem da análise cuidadosa de categorias como mais-valor, força de trabalho, mercadoria, dinheiro, capital, etc. Estas figuras mais próximas são aquelas como lucro, juros, renda, que, por si mesmas, não se explicam. É necessário que, por exemplo, o mais-valor seja compreendido para que se entenda que estas três figuras mencionadas - que parecem ser quase que naturais aos agentes da produção e da circulação -, que, em verdade, são parcelas do montante de mais-valor produzido na esfera produtiva. O livro I procura explicitar formas econômicas (oikonomischen Formen) como mercadoria, dinheiro, capital, mostrando como que a produção capitalista de mercadorias está assentada na compre e venda da força de trabalho e, portanto, na produção do mais-valor. O livro III, por sua vez, analisa, dentre outras questões, como que figuras econômicas (oikonomischen Gestalten) como lucro, renda, juros, ao mesmo tempo, dependem da produção de mais-valor e parecem prescindir da mesma. O livro II, por sua vez, ao tratar do processo de circulação de capital - em que a reprodução ampliada e a acumulação de capital se colocam -, de certo modo, é um elo mediador entre estes dois extremos. ${ }^{6}$

A exposição marxiana vai do abstrato ao concreto (Cf. MARX, 1996 a, 2011), começando pela mercadoria, no livro I e chegando ao capítulo inconcluso sobre as classes sociais, no livro III. Aliás, a diferença no grau de concretude fica muito clara quando se nota que no processo de produção imediato, Marx trata principalmente do moderno proletariado, da burguesia e dos proprietários fundiários, ao passo que no livro II, e principalmente no livro III,

\footnotetext{
${ }^{6}$ Para uma análise da arquitetura e da feitura de $O$ capital, Cf. ROSDOLSKY, 2001.
} 
diversas outras classes e parcelas de classes aparecem de modo muito mais evidente e com muito maior proeminência no processo econômico. E, assim, se é verdade que as lutas entre as diferentes classes, em suas complexidades, são muito mais palpáveis de imediato, também é verdadeiro que elas só podem ser compreendidas tendo-se em conta, por exemplo, o que é a mercadoria, o dinheiro e o capital. Para se compreender o modo de produção capitalista, seria preciso também se ter em conta que a oposição fundante deste forma de produção se dá entre burguesia e proletariado, o que é tratado no livro I. Ao mesmo tempo, o processo de circulação (livro II) e o processo global de produção (livro III) trazem oposições e contradições essenciais para a compreensão da moderna produção de mercadorias, mesmo que tais contradições, por vezes, não tenham na oposição entre proletariado e burguesia sua conformação imediata. Marx já havia mencionado que na arquitetura de O capital, tal qual já havia dito Marx nos Grundrisse, ao mesmo tempo em que o concreto é “o ponto de partida efetivo” (MARX, 2011, p. 78), “o concreto é concreto porque é a síntese de múltiplas determinações, portanto, unidade da diversidade. Por essa razão, o concreto aparece no pensamento como processo da síntese, como resultado, não como ponto de partida" (MARX, 2011, p. 78-79) ${ }^{7}$; ou seja, não obstante o conhecimento parta sempre da concretude em sua imediatez (que aparece, sobretudo no livro III de $O$ capital), a compreensão do processo pelo qual o concreto se conforma como tal precisa de abstrações ${ }^{8}$, que aparecem em seu grau máximo no livro I.

Para que nos coloquemos mais diretamente sobre nosso tema: a circulação de mercadorias é muito mais palpável que os pressupostos de sua produção; a primeira, porém, só pode ser entendida com cuidado a partir da última. A exposição marxiana, assim, não é aleatória,

\footnotetext{
${ }^{7} \mathrm{Na}$ passagem em sua íntegra, diz Marx que "o concreto é concreto porque é a síntese de múltiplas determinações, portanto, unidade da diversidade. Por essa razão, o concreto aparece no pensamento como processo da síntese, como resultado, não como ponto de partida, não obstante seja o ponto de partida efetivo e, em consequência, também o ponto de partida da intuição e da representação. Na primeira via, a representação plena foi volatilizada em uma determinação abstrata; na segunda, as determinações abstratas levam à reprodução do concreto por meio do pensamento. Por isso, Hegel caiu na ilusão de conceber o real como resultado do pensamento que sintetiza-se em si, aprofunda-se em si e movimenta-se a partir de si mesmo, enquanto o método de ascender do abstrato ao concreto é somente o modo do pensamento de apropriar-se do concreto, de reproduzi-lo como um concreto mental. Mas de forma alguma é o processo de gênese do próprio concreto. [...] a totalidade concreta como totalidade de pensamento como um concreto de pensamento, é de fato um produto do pensar, do conceituar; mas de forma alguma é um produto do conceito que pensa fora e acima da intuição e da representação, e gera a si próprio, sendo antes produto da elaboração da intuição e da representação em conceitos. O todo como um todo de pensamentos, tal como aparece na cabeça, é um produto da cabeça pensante que se apropria do mundo do único modo que lhe é possível, um modo que é diferente de sua apropriação artística, religiosa e prático-mental. O sujeito real, como antes, continua a existir em sua autonomia fora da cabeça; isso, claro, enquanto a cabeça se comportar apenas de forma especulativa, apenas teoricamente. Por isso, também no método teórico o sujeito, a sociedade, tem de estar continuamente presente como pressuposto da representação.” (MARX, 2011, p. 78-79)

${ }^{8}$ Sobre as abstrações razoáveis em Marx, Cf. CHASIN, 2009.
} 
mas, de certo modo, é parte de sua própria crítica imanente ao modo de produção capitalista. (Cf. GRESPAN, 2019) ${ }^{9}$ Em, verdade, muitas vezes, os homens se deparam com aquilo trazido no livro II antes de o processo de produção imediato lhes ser compreensível e, assim - diz Marx em $O$ capital, tal qual nos Grundrisse em diálogo e em antítese a Hegel (Cf. SARTORI, 2014) - que "é, sem dúvida, necessário distinguir o método de exposição formalmente do método de pesquisa." E, deste modo, "a pesquisa tem de captar detalhadamente a matéria, analisar as suas várias formas de evolução e rastrear sua conexão íntima." A exposição, portanto, somente seria possível depois da apreensão das determinações da materialidade e, portanto, "só depois de concluído esse trabalho é que se pode expor adequadamente o movimento real." (MARX, 1996 a, p. 140) Os diferentes níveis de abstração, assim, estão colocados de modo indissociável na realidade. Porém, para que, com a ciência, seja possível sair do nível aparente em direção à essência - "e toda a ciência seria supérflua se a forma de manifestação e a essência das coisas coincidissem imediatamente" (MARX, 1986 b, p. 271) - é necessário aquilo que Marx chamou abstração razoável. (Cf. CHASIN, 2009) E, percebendo-se que as abstrações são expressões da própria realidade, é necessário compreender os diferentes níveis de abstração, daqueles mais fenomênicos aos mais essenciais à conformação objetiva do modo de produção capitalista. (Cf, LUKÁCS, 2013; CHASIN, 2009)

Há de se ter isto em conta para que as formas de apresentação das categorias da economia capitalista possam ser compreendidas em correlação com a essência que se apresenta nas diversas figuras econômicas que compõem a imediatez da sociedade capitalista. (Cf. GRESPAN, 2019; SARTORI, 2019 a, b) O livro II precisa ser compreendido à luz do livro I e vice-versa, certamente. E, claro, essência e aparência não são um par dialético que se coloque no nível simplesmente epistemológico; são, constitutivos da efetividade. ${ }^{10} \mathrm{~A}$ exposição marxiana traz o desenvolvimento da própria efetividade, explicitando, em momentos distintos, mas claramente interligados, a "figura medular interna, essencial mas oculta" (MARX, 1986 b, p. 160) e as figuras fenomênicas, que dependem da primeira em suas constituições efetivas, ao

\footnotetext{
${ }^{9}$ Este aspecto da exposição marxiana é importante, porém, não pode ser exagerado. Para Marx, "é, sem dúvida, necessário distinguir o método de exposição, formalmente, do método de pesquisa.” (MARX, 1996 a, p. 140) ao passo que, muitas vezes se nota em uma aproximação exagerada entre os métodos de Marx e Hegel é o seguinte: “o que se observa é o encobrimento do modo de pesquisa pelo modo de exposição das categorias". (ALVES, 2013, p. 10) Acreditamos que mesmo um grande autor como Reicheld talvez incorra neste erro ao dizer que "Marx caracterizou sua relação com Hegel com um coqueteio com a linguagem hegeliana" e continua, marcando sua posição, "isto não só é uma subestimação dos fatos, mas um evidente despiste, porque se verifica uma profunda coincidência na estruturação conceitual." (REICHELD, 2013, p. 20) Para uma breve análise sobre este ponto, Cf. SARTORI 2014.

${ }^{10}$ Sobre esta questão, Cf. LUKÁCS, 2013.
} 
mesmo tempo em que as ocultam. As figuras econômicas que permeiam o livro III e, em parte o livro II, não podem ser explicadas por si mesmas, ao mesmo tempo em que não deixam de ter um efeito ativo sobre as formas econômicas tratadas no livro I e que constituem o essencial da figura interna do modo de produção capitalista. E, também por isso, um estudo da arquitetura de $O$ capital não tem interesse meramente filológico.

A noção de produção, presente no livro I, e relacionada ao processo de trabalho, por exemplo, é bastante importante para a compreensão de $O$ capital e das formas e das figuras econômicas que aparecem em toda a extensão desta obra. Ela sempre contém determinações que a especificam, que trazem sua diferença específica, mas que, ao mesmo tempo, fazem parte, em seu nível mais geral, da própria realidade efetiva; como diz Marx, "a produção em geral é uma abstração, mas uma abstração razoável, na medida em que efetivamente destaca e fixa o elemento comum, poupando-nos assim da repetição" (MARX, 2011, p. 56) ${ }^{11}$. A produção em geral, portanto, não pode ser percebida em sua concretude, de imediato, com os sentidos; é necessário um exercício de abstração, em que - após compreender a conexão íntima da matéria - expõem-se seu movimento real. Para o que nos diz respeito mais imediatamente, podemos dizer que as abstrações do livro I - como a própria noção de produção, destacada também na famosa introdução aos Grundrisse - próximas do processo imediato de produção, espelham os elementos essenciais da constituição da relação-capital; ao mesmo tempo, porém, neste livro, a exposição ainda não deixa claro ao leitor o modo pelo qual a acumulação de capital se dá, a partir da realização do mais-valor e do reinvestimento na própria produção, que remete, no limite, ao mercado mundial. No livro II, por seu turno, esta questão é esclarecida e a “acumulação de capital, isto é, a acumulação capitalista real” (MARX, 1985, p. 378) é analisada com mais cuidado, em meio ao processo de circulação de mercadorias e à relação entre a produção de meios de produção (departamento I) e a produção de meios de consumo (departamento II). As abstrações, assim, fazem parte do próprio movimento da realidade, são, como diz Marx, categorias que conformam "formas de ser, determinações de existência" (MARX, 2011, 85), e assim, são partes da própria matéria. (Cf. LUKÁCS, 2013)

Porém, deve-se destacar algo sobre a exposição do livro II: camadas do capital (como o

${ }^{11}$ Diz Marx na passagem na íntegra: “a produção em geral é uma abstração, mas uma abstração razoável, na medida em que efetivamente destaca e fixa o elemento comum, poupando-nos assim da repetição. Entretanto, esse Universal, ou o comum isolado por comparação, é ele próprio algo multiplamente articulado, cindido em diferentes determinações. Algumas determinações pertencem a todas as épocas; outras são comuns apenas a algumas.[Certas]determinações serão comuns à época mais moderna e à mais antiga. Nenhuma produção seria concebível sem elas." (MARX, 2011, p. 56) Para um estudo cuidadoso das abstrações, Cf. CHASIN, 2009. 
capital comercial), que não produzem mais-valor, ganham espaço; deste modo, o centro daquilo que é tratado afasta-se progressivamente da essência da conformação mais basilar do modo de produção capitalista, a exploração da mercadoria força de trabalho, trazida à tona no livro I. O livro II, portanto, trata de algo que é de grande importância para que o modo de produção capitalista possa se reproduzir concretamente em meio à acumulação de capital - e sem que se entenda isso, não há como haver uma análise crítica deste sistema produtivo -; porém, com isso, na exposição marxiana, a produção de mais-valor está pressuposta, de modo que uma leitura parcial de $O$ capital - também devido à questão que tratamos neste momento - pode levar a sérios equívocos: de um lado, ao se centrar no livro I, à centralidade excessiva na oposição entre burguesia industrial e proletariado; doutro, no livro II, pode-se ter a ênfase demasiada na acumulação de capital, e nos esquemas de reprodução. Caso coloca-se a tônica somente no livro III, ganhariam espaço o capital portador de juros, a renda, o setor de serviços, as camadas intermediárias, etc. ${ }^{12}$ Há uma unidade em $O$ capital e ela precisa ser compreendida para que se analise a obra marxiana devidamente ${ }^{13}$. Assim, diz Marx:

O processo direto de produção do capital é seu processo de trabalho e de valorização, o processo cujo resultado é o produto-mercadoria e cujo motivo determinante é a produção de mais-valia. O processo de reprodução do capital abrange tanto esse processo direto de produção como ambas as fases do processo de circulação propriamente dito, isto é, o ciclo global, que como processo periódico - processo que se repete em períodos determinados sempre de novo - constitui a rotação do capital. [...] Cada capital individual constitui, entretanto, apenas uma fração autonomizada do capital social total, dotada, por assim dizer, de vida individual, assim como cada capitalista individual constitui apenas um elemento individual da classe capitalista. $\mathrm{O}$ movimento do capital social consiste na totalidade dos movimentos de suas frações autonomizadas, das rotações dos capitais individuais. Tal como a metamorfose da mercadoria individual é um elo da série de metamorfoses do mundo das mercadorias - da circulação de mercadorias -, assim a metamorfose do capital individual, sua rotação, é um elo no ciclo do capital social. (MARX, 1985, p. 261)

A produção do valor, sua realização e expansão ligam-se à reprodução do capital. Tratase de momentos distintos, mas integrados, do movimento do capital social. A rotação do capital, bem como o tempo de rotação do capital também são essenciais para a acumulação de capital. Nela, ao mesmo tempo, coloca-se o capital social e os capitais individuais, estes últimos que se relacionam, ao mesmo tempo, com suas autonomizações e indissociabilidades. Os capitalistas individuais, na acumulação, são um elo na conformação da classe capitalista e no modo pelo

\footnotetext{
${ }^{12}$ Sobre o modo como estas questões, bastante pungentes hoje, aparecem em Marx Cf. SARTORI, 2019 b, c.

${ }^{13}$ Sobre o assunto, bem como sobre a relação dos Grundrisse com O capital, cf. ROSDOLSKY, 2001.
} 
qual se coloca o ciclo do capital total; as mercadorias individuais, um elo nas metamorfoses do mundo das mercadorias, que se apresentam no processo de circulação. Tais temas são de grande relevo na exposição do livro II de $O$ capital. E, assim, é preciso notar que nosso assunto, o Direito no livro II, envolve compreender o papel do momento jurídico na acumulação de capital e no processo de circulação de mercadorias. A questão pode ser importante para este texto, para os estudos sobre Marx, sobre o marxismo e sobre o papel do Direito na crítica à sociedade capitalista. Aqueles que, como nós, acreditam que a análise marxiana do modo de produção capitalista essencialmente acertada, diriam, inclusive, que o tema pode ajudar no entendimento do próprio sistema capitalista de produção.

E, neste ponto, é preciso ressaltar: praticamente não há estudos de fôlego sobre o tema.

Na esteira de Isaac Rubin (1987), Pachukanis enfatiza o modo de produção capitalista como algo eivado pela circulação mercantil, chegando, por vezes, a tomar sociedade capitalista e sociedade mercantil como sinônimas. O autor soviético, inclusive, coloca como central o Direito em meio à circulação de mercadorias e, principalmente, na compra e venda da força de trabalho (Cf. PACHUKANIS, 2017); ocorre, porém, que - como bem destacou Vinícius Casalino (2011) ao analisar a obra marxiana - é preciso que se enfoque, não só na reprodução simples de capital (M-D-M/D-M-D), mas na reprodução ampliada (D-M-D'), ou seja, na acumulação de capital, tratada no livro II $^{14}$. Segundo o autor de $O$ capital, seria um erro enorme confundir a produção de mercadorias com a produção capitalista de mercadorias. Diz-se, assim, no livro II: “Adam Smith identifica a produção de mercadorias em geral com a produção capitalista de mercadorias; os meios de produção de antemão são capital e o trabalho é de antemão trabalho assalariado." (MARX, 1985, p. 287) Com isto, perder-se-ia de vista que, na sociedade capitalista, a produção de mercadorias é a produção de mais-valor e leva à frente o processo de autovalorização do valor: "a circulação do capital-mercadoria implica a circulação da mais-valia, portanto as compras e vendas, por meio das quais os capitalistas medeiam seu consumo individual, o consumo da mais-valia." (MARX, 1985, p. 262) A riqueza que se apresenta no modo de produção capitalista nas mercadorias é produzida no processo imediato de produção, embora somente se realize como valor efetivamente no processo de circulação. A acumulação de capital, portanto, é a expansão do mais-valor, não sendo possível falar da sociedade capitalista somente como uma sociedade mercantil; ela é marcada pela expansão do

\footnotetext{
${ }^{14}$ Casalino (2011), neste ponto, critica Pachukanis. Não entraremos neste debate. Porém, enfatizamos aqui que se trata de diferentes, e complementares, níveis de abstração, de modo que a questão é bastante meandrada.
} 
valor e da produção, pela acumulação de capital, que se realiza no processo de circulação.

Se é verdade o que Casalino (2011) coloca, embora existam méritos indubitáveis na abordagem pachukaniana, ela trata somente de um dos graus de abstração de $O$ capital. E, assim, é preciso ter em conta diversos outros aspectos, que não são enfatizados pelo autor da Teoria geral do Direito e o marxismo. Marx é explícito ao dizer que "a reprodução simples em escala constante aparece como uma abstração”, uma abstração razoável no grau de concretude do livro I de $O$ capital. No entanto, ao passo que, ao enfatizar o processo de circulação, isto se dá "à medida que é estranho supor, de um lado, na base do sistema capitalista, a ausência de toda acumulação ou reprodução em escala ampliada e, de outro, que as condições em que se produz não permanecem absolutamente iguais em diversos anos.” (MARX, 1985, p. 293) Ou seja, ao se ter em conta a reprodução ampliada, ao mesmo tempo, há de se analisar a acumulação de capital e o desenvolvimento desigual das diferentes formações sociais capitalistas ${ }^{15}$. A autovalorização do valor, assim, somente é possível mediante o processo de circulação de mercadorias. Nele, no comércio mundial - colocado de modo mais ou menos desigual e, por vezes, por meio de guerras (Cf. LUXEMBURGO, 1985; HARVEY, 2006, 2014) -, o valor pode ser realizado em meio ao processo mundial de circulação de mercadorias. Comércio exterior e reprodução ampliada, portanto, são indissolúveis. Mas, é preciso que se aponte: em O capital, Marx não pode tratar das minúcias do comércio mundial, não havendo no livro II uma análise pormenorizada sobre o assunto.

Não existe produção capitalista sem comércio exterior. Mas, quando se supõe a reprodução anual normal em dada escala, supõe-se também que o comércio exterior apenas repõe artigos locais por artigos diferentes na forma útil ou natural, sem afetar as relações do valor, portanto também as relações de valor em que as duas categorias, meios de produção e meios de consumo, se convertem mutuamente e tampouco as proporções entre capital constante, capital variável e mais-valia, em que o valor do produto de cada uma dessas categorias é decomponível. A inclusão do comércio exterior na análise do valor-produto anualmente reproduzido só pode, portanto, confundir, sem proporcionar nenhum momento novo, seja do problema, seja de sua solução. Por isso, deve-se abstraí-lo inteiramente; portanto, aqui, também o ouro há de ser tratado como elemento direto da reprodução anual, e não como elemento mercantil introduzido de fora, por meio de intercâmbio. (MARX,1985, p. 343)

No livro II de $O$ capital, é essencial a compreensão das determinações gerais da reprodução ampliada. Para isso, segundo Marx, seria central a análise das relações estabelecidas entre o departamento I e o departamento II da economia, bem como entre os diferentes

\footnotetext{
${ }^{15}$ Somente para que não fiquemos silentes sobre o assunto, vale mencionar o papel que Rosa Luxemburgo desempenhou neste estudo. Cf. LUXEMBURGO, 1985.
} 
componentes do capital. Assim, mesmo que o mercado mundial - com o comércio externo e com as guerras - seja uma condição sem a qual o sistema capitalista de produção não se sustenta, o autor alemão não pode aprofundar-se na questão no grau de abstração em que sua exposição se coloca no texto que aqui tratamos. Buscando apreender a reprodução do capital e as leis gerais da acumulação capitalista, não haveria como (naquele momento da exposição) dar um passo a mais em direção à concretude da sociedade capitalista em sua efetividade. O grau de abstração do livro II, assim, é bastante menos acentuado que aquele do livro I, em certo sentido. Ao mesmo tempo, há de se notar que o modo de produção capitalista como aparece no livro II é bastante menos complexo do que o modo como ele efetivamente conforma-se em suas múltiplas determinações. Há abstrações aqui, portanto. Abstrações razoáveis, certamente. Isto faz com que o livro III de $O$ capital (bem como textos de análise histórica como Guerra civil na França, Luta de classes na França, O 18 Brumário, bem como os textos da Nova Gazeta renana) aproxime-se muito mais da imediatidade da sociedade capitalista que o livro que aqui tratamos; e, deve-se destacar: mesmo neste livro, não se tem uma análise detalhada do mercado mundial, do Estado e das guerras. Assim como o processo de circulação é o elo intermediário entre o processo imediato de produção e as figuras econômicas concretas do processo global de produção, o livro II aparece como um elo intermediário na arquitetura de $O$ capital. Isto faz com que temas essenciais, como a acumulação de capital, o desequilíbrio entre os dois departamentos da economia, o comércio externo e o mercado mundial apareçam, mas somente em seus elementos mais gerais. (Cf. HARVEY, 2014) Mas, mesmo assim, acreditamos que o tratamento do Direito neste processo possa ser bastante importante.

O lugar do livro II é bastante peculiar e, inclusive, é negligenciado hoje em dia (Cf. HARVEY, 2014), tendo-se uma ênfase muito maior no estudo dos livros I e III. O assunto seria essencial, inclusive, para que se discutisse a natureza do dinheiro no socialismo ${ }^{16}$. No entanto, aqui não podemos tratar deste e de outros assuntos. Somente destacamos os elementos mais gerais da arquitetura do livro II para que deixemos claro que seu estudo, quando se trata do Direito, é de grande valia. E isto se dá mesmo que vá se chegar à conclusão segundo a qual -

\footnotetext{
${ }^{16}$ Diz Marx que "na produção social, do mesmo modo que na capitalista, os trabalhadores dos ramos de negócios com períodos curtos de trabalho retirarão, depois como antes, produtos apenas por curto tempo sem dar produtos de volta; enquanto nos ramos de negócios com períodos longos de trabalho retiram continuamente por longo tempo antes de devolver. Essa circunstância decorre, portanto, das condições materiais do processo de trabalho em questão e não de sua forma social. O capital monetário na produção social é eliminado. A sociedade distribui força de trabalho e meios de produção entre os diferentes ramos de negócios. Os produtores podem receber, por fim, vales de papel com os quais retiram das reservas sociais de consumo um quantum correspondente a seu tempo de trabalho. Esses vales não são dinheiro. Eles não circulam” (MARX,1985, p. 265-266).
} 
ao contrário do que os estudiosos do Direito podem pensar - o aspecto jurídico não exerceria, de acordo com Marx, um papel essencial no processo de circulação de mercadorias, sendo este processo engendrado, no âmbito econômico mesmo. Mais à frente trataremos do assunto, pois é necessário que se analise a extensão do papel do Direito na acumulação de capital e no processo de circulação de mercadorias, processo este que traz consigo a realização do maisvalor. Isto se dá, primeiramente, para que se possa compreender com cuidado a obra de Marx (bem como a realidade que ele tratou), mas também porque a importância do aspecto jurídico, na leitura pachukaniana, é bastante grande, tendo-se, para este autor, o Direito como mediação essencial na produção do mais-valor. Mesmo que os méritos do jurista soviético sejam muitos, é preciso que se analise a obra de Marx em graus de abstração com os quais o autor de Teoria geral do Direito e o marxismo não se preocupou.

\section{Reprodução ampliada e circulação capitalista de mercadorias: as formas econômicas de $\boldsymbol{O}$ capital e o Direito}

A produção de mercadorias não se confunde com a produção capitalista de mercadorias. E, assim, há de se perceber, também por isso, que não é possível trazer a noção de sociedade mercantil como sinônima de sociedade capitalista. Marx é bastante claro ao trazer à tona sua crítica a Smith, que vem a tornar o trabalho assalariado (e a própria relação-capital) como algo, de certo modo, supra-histórico. O autor ataca também o pensador de A riqueza das nações por outras razões, dentre elas, sua concepção de trabalho e de trabalho produtivo em específico. (Cf. MARX, 1980; SARTORI, 2018) E, assim, destaca que, na reprodução ampliada do capital, não se tem simplesmente a incrementação das forças produtivas e do montante de riqueza, há também uma espécie de sujeito automático, que se coloca no valor, na autovalorização do valor; ele se expressa em formas diferentes de aparição, fetichizadas, e que parecem ser por si só subsistentes na medida em que nunca podem ser. Diz Marx sobre o valor, no livro I, que "ele passa continuamente de uma forma para outra, sem perder-se nesse movimento, e assim se transforma num sujeito automático" (MARX, 1996 a, p. 273) ${ }^{17}$ de tal maneira que a produção

\footnotetext{
${ }^{17}$ Veja-se a passagem na íntegra: "as formas autônomas, as formas dinheiro, que o valor das mercadorias assume na circulação simples mediam apenas o intercâmbio de mercadorias e desaparecem no resultado final do movimento. Na circulação $\mathrm{D}-\mathrm{M}-\mathrm{D}$, pelo contrário, ambos, mercadoria e dinheiro, funcionam apenas como modos diferentes de existência do próprio valor, o dinheiro o seu modo geral, a mercadoria o seu modo particular, por assim dizer apenas camuflado, de existência. Ele passa continuamente de uma forma para outra, sem perderse nesse movimento, e assim se transforma num sujeito automático. Fixadas as formas particulares de aparição, que o valor que se valoriza assume alternativamente no ciclo de sua vida, então se obtêm as explicações: capital é dinheiro, capital é mercadoria. De fato, porém, o valor se torna aqui o sujeito de um processo em que ele, por meio
} 
capitalista se dá impondo potências estranhas como se naturais fossem. (Cf. SARTORI, 2019 a) A forma dinheiro e a forma capital, por exemplo, aparecem à representação dos agentes de produção como algo que tem existência plenamente autônoma, e que poderiam ser tratados por si próprios, trazendo um peculiar modo de representação (Cf. GRESPAN, 2019); ao mesmo tempo, segundo Marx, seria preciso perceber que a autonomização destas formas econômicas (que nunca subsistem por si sós fora do processo produtivo) é somente um elo mediador na produção, mesmo que ele seja extremamente importante.

As circunstâncias mais básicas da produção capitalista, relacionadas à conformação da relação-capital ${ }^{18}$, dão a tônica da transformação da circulação simples de mercadorias, que está presente, por exemplo, na sociedade romana, na sociedade russa do século XIX, entre outras sociedades, para a circulação de mercadorias assentada sobre a produção capitalista. Assim, por mais que Marx tenha tratado primeiramente da mercadoria, depois do dinheiro no livro I, sua exposição supõe o desenvolvimento da relação capitalista de produção, que, também neste livro, é vista em suas determinações mais basilares. (Cf. ROSDOLSKY, 2001) Sem estas últimas, tem-se mercadoria e dinheiro em outras formas de produção de mercadorias que não a capitalista. E, para nosso tema, é essencial que isto seja trazido à tona porque Pachukanis (2017) associa diretamente a circulação de mercadorias com a existência do Direito, este último que só existiria no modo de produção capitalista. Para Marx, por outro lado, tanto a circulação de mercadorias quanto a mediação da esfera jurídica são, em verdade, anteriores ao capitalismo Marx menciona diversas vezes, por exemplo, o Direito romano e a sociedade antiga. E, neste sentido, continua sendo preciso que a diferença específica entre as diversas conformações das mercadorias e das sociedades seja também trazida à tona; trata-se, em verdade, de uma agenda que pode ser importante, inclusive, para os estudos críticos sobre o Direito, como aqueles realizados pela crítica marxista ao Direito.

Marx é bastante claro no livro II de $O$ capital sobre a produção de mercadorias, a

de uma mudança constante das formas de dinheiro e mercadoria, modifica a sua própria grandeza, enquanto maisvalia se repele de si mesmo, enquanto valor original, se autovaloriza. Pois o movimento, pelo qual ele adiciona mais-valia, é seu próprio movimento, sua valorização, portanto autovalorização. Ele recebeu a qualidade oculta de gerar valor porque ele é valor. Ele pare filhotes vivos ou ao menos põe ovos de ouro." (MARX, 1996 a, p. $273-$ 274)

${ }^{18}$ Como diz Marx, “a relação-capital pressupõe a separação entre os trabalhadores e a propriedade das condições de realização do trabalho. Tão logo a produção capitalista se apoie sob os próprios pés, não apenas conserva tal separação, mas a reproduz em escala sempre crescente. Portanto, o processo que cria a relação-capital não pode ser outra coisa que não o processo de separação entre o trabalhador e a propriedade das suas condições de trabalho, um processo que por um lado transforma os meios sociais de subsistência e de produção em capital, por outro, os produtores imediatos em operários assalariados.” (MARX, 1996 b, p. 252) 
generalização da circulação destas e, por fim, a conformação capitalista da produção mercantil:

As mesmas circunstâncias que produzem a condição básica da produção capitalista - a existência de uma classe de trabalhadores assalariados requerem a passagem de toda a produção de mercadorias para a produção capitalista de mercadorias. À medida que esta se desenvolve, tem o efeito de decompor e de dissolver cada forma antiga de produção, a qual, orientada preferencialmente para o autoconsumo direto, só transforma o excedente do produto em mercadoria. Ela faz da venda do produto o interesse principal, primeiro sem aparentemente atacar o próprio modo de produção, como foi, por exemplo, o primeiro efeito do comércio mundial capitalista sobre povos como os chineses, indianos, árabes etc. Mas, em segundo lugar, onde tenha fincado raízes, ela destrói todas as formas de produção mercantil que se baseiem seja no trabalho do próprio produtor, seja apenas na venda do produto excedente como mercadoria. Ela generaliza primeiro a produção de mercadorias e transforma depois gradualmente toda a produção de mercadorias em produção capitalista. (MARX, 1985, p. 32)

A circulação de mercadorias que parte da autovalorização do capital traz a expansão da relação-capital, ou seja, é indissolúvel da acumulação de capital. Porém, a consolidação das relações capitalistas de produção no âmbito nacional não necessariamente se dá de imediato e sem atritos; antes, tem-se o contrário: na dissolução de formas sociais pré-capitalistas - por vezes comunitárias, e ligadas ao autoconsumo direto ${ }^{19}$-, a expansão da circulação das mercadorias tem um papel, primariamente, de dissolução. A função do comércio mundial capitalista sobre os árabes, os chineses, os indianos, por exemplo, é tal que, de imediato, parece que é possível se manter o antigo modo de produção conjuntamente com as trocas mercantis propriamente capitalistas. E, de fato, isto se daria por algum tempo. E, assim, conviveriam a produção mercantil não capitalista com a produção mercantil capitalista. Porém, o colonialismo, bem como a expansão comercial capitalista (seja por meio da concorrência, seja por meio de guerras), trazem consigo a acumulação de capital e, por isso, também a potencial sobreposição da produção de mercadorias pela produção capitalista de mercadorias. Ou seja, o movimento da circulação mercantil passa de M-D-M, e de D-M-D, para D-M-D', em que o dinheiro ganha uma importância bastante grande: a acumulação de dinheiro volta-se para o investimento produtivo e, portanto, para a acumulação de capital. O dinheiro só se coloca como tal, no capitalismo, na medida em que sua acumulação implica, ao mesmo tempo, em sua

\footnotetext{
${ }^{19}$ A diferença entre estas formações sociais é enorme. A China, a Índia e a Rússia tiveram formas comunais de organização da produção, mas duas delas passaram pela invasão do colonizador estrangeiro e a outra, segundo Marx, poderia se aproveitar da forma comunal de produção para a passagem ao socialismo. (Cf. MARX; ENGELS, 2013) Para uma análise das peculiaridades nacionais destes países e as diferenças no que toca o papel do Direito e da propriedade privada, Cf. SARTORI, 2017 a. Para uma análise da questão russa em Marx, Cf. MACHADO, 2017.
} 
autonomização e em seu futuro - e bastante mediado (Cf. MARX, 1986 a, b) - retorno ao solo da produção. O movimento da circulação de mercadorias que Marx mostra na passagem acima é aquele em que, pelo próprio impulso e pela compulsão da lei do valor, a produção de mercadorias - primeiramente mediante a universalização da troca mercantil - leva tendencialmente (e as leis do sistema capitalista de produção são sempre tendenciais) à superação da produção de mercadorias pela produção capitalista de mercadorias. A venda do produto só se torna o interesse principal na circulação ao passo que subjaz a ela a autovalorização do valor e a acumulação de capital.

Devemos dizer que, em verdade, há ainda diversas questões de grande relevo na passagem de Marx, como, por exemplo, a necessária análise do modo como a produção de mercadorias se coloca em sociedades não capitalistas distintas, como aquelas dos chineses, dos árabes, dos indianos e, podemos acrescentar, dos russos. Seria interessante tratar da relação do colonialismo, do desenvolvimento das forças produtivas, do Direito e do Estado para que - a partir de uma análise que passa por parte essencial do livro II de $O$ capital - se chegasse a conclusões importantes sobre o desenvolvimento real e efetivo da sociedade capitalista. (Cf. SARTORI, 2017) A dissolução de sociedades pré-capitalistas, bem como os momentos de transição entre a produção mercantil para a produção mercantil capitalista necessitam de um estudo mais profundo também; e tem-se ainda o modo pelo qual os produtores diretos também podem se colocar como produtores de mercadorias. Aqui, porém, não podemos avançar nesta pesquisa, que, por mais relevante que possa ser, requer referência substancial a diversos outros textos de Marx. Podemos, porém, para os fins deste artigo, trazer à tona as transformações na produção que advém da imposição do sujeito automático do capital, da autovalozação do valor, que, como já dissemos, remete à acumulação de capital. Veja-se o que diz Marx no livro II sobre a compra e venda da força de trabalho ao ter em conta o dinheiro:

Embora portanto, no ato D - FT, o possuidor do dinheiro e o possuidor da força de trabalho só se relacionem reciprocamente como comprador e vendedor, confrontando-se como possuidor de dinheiro e possuidor de mercadorias, por esse lado portanto só se encontrem um com o outro em mera relação monetária - ainda assim, o comprador de antemão aparece simultaneamente como possuidor dos meios de produção, que constituem as condições objetivas do dispêndio produtivo da força de trabalho por seu possuidor. Em outras palavras: esses meios de produção se contrapõem ao possuidor da força de trabalho como propriedade alheia. Por outro lado, o vendedor de trabalho se confronta com seu comprador como força de trabalho alheia, que tem de passar a seu domínio e ser incorporada a seu capital, para que este funcione efetivamente como capital produtivo. A relação de classe entre capitalista e trabalhador assalariado já existe, já está pressuposta no momento em que 
ambos se defrontam no ato D - FT FT - D, da perspectiva do trabalhador. E compra e venda, relação monetária, porém uma compra e uma venda em que se pressupõem o comprador como capitalista e o vendedor como trabalhador assalariado, e essa relação está dada pelo fato de que as condições para a realização da força de trabalho - meios de subsistência e meios de produção estão separadas, como propriedade alheia, do possuidor da força de trabalho. (MARX,1985, p. 29)

Se Pachukanis enfoca o primeiro parágrafo do segundo capítulo do livro I de $O$ capital, faz isto trazendo à tona certa centralidade do Direito, que viria a ser essencial para a própria extração do mais-valor. Para isto, seriam essenciais tanto o sujeito de direito quanto a igualdade jurídica. (Cf. PACHUKANIS, 2017) Aqui, porém, Marx não traz tanto à tona o papel do Direito na compra e venda da mercadoria força de trabalho (FT), mas o papel que tem o dinheiro.

$\mathrm{Na}$ passagem analisada por Pachukanis ${ }^{20}$ a forma contratual é uma mediação entre a vontade dos possuidores de mercadoria - o comprador e o vendedor - e o reconhecimento das pessoas como proprietários. Este reconhecimento se dá, segundo o autor da Teoria geral do Direito e o marxismo, por meio da "forma jurídica" 21 , colocada por meio da noção de igualdade, mais precisamente, da igualdade jurídica. (Cf. PACHUKANIS, 2017) Aqui, porém, o elo mediador entre o comprador e o vendedor é o dinheiro. Se, como dissemos anteriormente, a análise do livro I e do livro II implica no reconhecimento de diferentes níveis de concretude, é preciso que analisemos com cuidado a passagem acima, em que não é o Direito ou a forma jurídica contratual que tem o maior relevo, mas o dinheiro. Quem enfatiza com maior destaque a relação entre igualdade jurídica e circulação de mercadorias é Engels, e não Marx. (Cf. ENGELS, KAUTSKY, 2012) E, é preciso que se diga: a passagem na qual Pachukanis se baseia está no primeiro parágrafo do segundo capítulo do livro I de $O$ capital, que trata justamente do processo de troca, que, por sua vez, supõe o dinheiro, que é tratado ao fim da sessão I de $O$

\footnotetext{
${ }^{20}$ Diz Marx: "as mercadorias não podem por si mesmas ir ao mercado e se trocar. Devemos, portanto, voltar a vista para seus guardiões, os possuidores de mercadorias. As mercadorias são coisas e, consequentemente, não opõem resistência ao homem. Se elas não se submetem a ele de boa vontade, ele pode usar a violência, em outras palavras, tomá-las. Para que essas coisas se refiram umas às outras como mercadorias, é necessário que os seus guardiões se relacionem entre si como pessoas, cuja vontade reside nessas coisas, de tal modo que um, somente de acordo com a vontade do outro, portanto, apenas mediante um ato de vontade comum a ambos, se aproprie da mercadoria alheia enquanto aliena a própria. Eles devem, portanto, reconhecer-se reciprocamente como proprietários privados. Essa relação jurídica, cuja forma é o contrato, desenvolvida legalmente ou não, é uma relação de vontade, em que se reflete uma relação econômica. O conteúdo dessa relação jurídica ou de vontade é dado por meio da relação econômica mesma." (MARX, 1996 a, p. 79) Para uma análise da passagem tendo em conta a arquitetura do livro I, Cf. SARTORI, 2019 a. A crítica à relação entre forma mercantil e jurídica se encontra também em PAÇO CUNHA, 2014.

${ }^{21}$ Colocamos entre parênteses a expressão pois, embora ela seja central a Pachukanis, ela aparece primordialmente no plural em Marx, tendo um significado diferente. São formas jurídicas, por exemplo, o contrato as transações jurídicas, as ficções jurídicas, entre outras. Elas aparecem preponderantemente no livro III de $O$ capital.
} 
capital. $^{22}$ Assim, é verdade que a exposição marxiana vai do abstrato ao concreto, mas igualmente verdadeiro é que a compreensão das abstrações razoáveis de Marx se dá também na medida em que elas se encontram presentes - mesmo que dissolvidas (Cf. LUKÁCS, 2013) no maior grau de concretude e, portanto, em um momento posterior da exposição. Dizemos isto porque a forma contratual - que implica no Direito, e na superação, ao menos nos elementos essenciais, do privilégio - se coloca como uma mediadora sem a qual os homens não se conformam como assalariados. Mas, no livro II, a conformação dos homens como assalariados e, portanto, a pressuposição da relação-capital já está colocada, de modo que Marx não precisa trazer à tona o elo entre a relação econômica e a relação jurídica; ele traz a mediação do dinheiro para que a força de trabalho possa ser incorporada ao capital e para que este se coloque, assim, como produtivo. O essencial, assim, é a relação entre a forma mercadoria e a forma dinheiro, e não a mediação jurídica.

O processo de troca também não aparece no livro II como aquele entre iguais, mas como um conjunto de atos que têm consigo agentes da produção em suas funções concretas: capitalistas, que possuem dinheiro (que se coloca como capital) e trabalhadores, que possuem a mercadoria força de trabalho. $\mathrm{O}$ ato D-FT, portanto, não é somente uma relação entre sujeitos de direito iguais, como alguns, dialogando com Pachukanis (2017), concluem a partir da leitura do livro I de $O$ capital; antes, as funções concretas dos indivíduos, como agentes da produção, têm como elo um terceiro elemento, que aparece como impessoal: não o Direito, mas o dinheiro. E, assim, do ponto de vista da reprodução do capital e da acumulação de capital, deve-se enfocar a autonomização da forma dinheiro, e não o eventual fetichismo da forma jurídica ${ }^{23}$. Os indivíduos, na compra e venda da força de trabalho, aparecem essencialmente como proprietários, sendo o dinheiro e a força de trabalho elos pelos quais se coloca o capital produtivo, pressupondo a relação de produção entre capitalista e trabalhador, no ato D-FT FTD. Tem-se, assim, uma forma de nivelação que não é propriamente jurídica e em que "como o dinheiro aparece aqui como material, como mercadoria universal dos contratos, toda diferença entre os contratantes é, ao contrário, apagada.” (MARX, 2011, p. 300) Ou seja, o nivelamento e a igualdade que se relacionam com a forma mercadoria, no livro II, está na forma dinheiro, que é uma das formas pelas quais - concretamente - representa-se o valor.

\footnotetext{
${ }^{22}$ Para uma crítica à leitura pachukaniana a partir da estrutura do livro I, principalmente ao se ter com conta $\mathrm{o}$ papel do dinheiro na exposição marxiana, Cf. CASALINO, 2019.

${ }^{23}$ Para uma crítica da concepção pachukaniana segunda a qual haveria um fetichismo específico da forma jurídica, Cf. PAÇO CUNHA, 2015.
} 
Trata-se de um processo que tem como suposto a formação do dinheiro na sociedade capitalista e, assim, diz Marx no próprio livro I: “como no dinheiro é apagada toda diferença qualitativa entre as mercadorias, ele apaga por sua vez, como leveller radical, todas as diferenças.” (MARX, 1996 a, p. 252) Ou seja, real e efetivamente, a igualdade jurídica se expressa em correlação com a troca mercantil, certamente, e, assim, Pachukanis traz um ponto importante. No entanto, há outras mediações para que seja possível que o Direito e a igualdade apareçam como tais no modo de produção capitalista; e, para entender isto, talvez seja essencial que se enfoque com mais cuidado também o dinheiro, que aparece como mercadoria universal: "o dinheiro mesmo, porém, é uma mercadoria, uma coisa externa, que pode converter-se em propriedade privada de qualquer um. O poder social torna-se, assim, poder privado da pessoa privada.” (MARX, 1996 a, p. 252) No livro II, portanto, aparece em maior grau de concretude aquilo que já estava explicitado no livro I: a conformação da igualdade entre os agentes da produção, embora passe pela mediação do Direito, é essencialmente econômica e passa pela forma dinheiro; esta última forma, inclusive, é algo importante para que o poder privado da pessoa privada tenha a proeminência que tem na sociedade capitalista. Só para que toquemos rapidamente em um outro ponto polêmico: a noção de pessoa privada que Marx menciona ao tratar do dinheiro não parece relacionar-se imediatamente à categoria sujeito de direito (Cf. SARTORI, 2019 a) Para que tragamos explicitamente algo que talvez não agrade toda uma linha de argumentação sobre marxismo e Direito: aquilo que se relaciona mais proximamente com a forma mercadoria não é tanto a forma jurídica, que seria central a Pachukanis, mas o dinheiro; e, assim, a crítica ao Direito implica, não só em enfatizar o papel que o Direito tem na conformação da exploração da força de trabalho, embora isto seja importante. Antes, há a necessidade de trazer à tona que o processo de troca tem consigo o dinheiro aparecendo como uma das metamorfoses da mercadoria, cuja substância está no valor, e na autovalorização do valor. O sujeito primordial a Marx, tanto no livro I quanto no livro II (e no livro III) não é o sujeito de direito, mas o sujeito automático do capital ${ }^{24}$. A relação essencial entre as formas sociais não está na dialética entre forma mercantil e "forma jurídica", mas nas correlações entre a forma mercadoria, a forma dinheiro, a forma capital e as figuras concretas da economia.

O fetichismo do dinheiro, assim, aparece em ato no livro II. E, ao se tratar do Direito neste livro, isto precisa ser enfatizado. Se, no livro I, tal fetichismo se expressa em correlação próxima com o fetichismo da mercadoria, para o tema que tratamos, a questão ganha força a

\footnotetext{
${ }^{24}$ Para uma crítica à ênfase pachukaniana no sujeito de direito, Cf. SARTORI, 2019 a.
} 
partir da autonomização da forma dinheiro. Disse Marx no livro I que "o enigma do fetiche do dinheiro é, portanto, apenas o enigma do fetiche da mercadoria, tornado visível e ofuscante." (MARX, 1996 a, p.216) E, assim, este elemento visível e ofuscante - correlacionado ao nivelamento que se dá pelo dinheiro - aparece com certa centralidade no processo de circulação de mercadorias. Se é verdade, como Marx destacou no livro I, que "a esfera da circulação ou do intercâmbio de mercadorias, dentro de cujos limites se movimentam compra e venda de força de trabalho, era de fato um verdadeiro éden dos direitos naturais do homem" (MARX, 1996 b, p. 144) ${ }^{25}$, o que faz com que esta forma de aparição e de representação se dê assim não é tanto um fetichismo inato ao Direito, mas a correlação entre o fetiche da mercadoria e do dinheiro. (Cf. PAÇO CUNHA, 2015) Acrescenta-se que o processo capitalista de produção precisa da extração de mais-valor, mas ele aparece na representação dos homens como se o dinheiro (tomado de forma hipostasiada) fosse o real objetivo, como mercadoria universal. No livro II, assim, há uma dependência grande diante do capital produtivo - e, portanto, do trabalho produtivo, aquele que produz mais-valor (Cf. COTRIM, 2013) - ao mesmo tempo, porém, há uma tentação sempre presente de tomar o dinheiro como o essencial e a produção somente como um mal necessário e, por vezes, passível de ser retirado da cena central.

E, assim, ao analisar do processo de circulação do capital, diz Marx sobre o assunto, ao tratar da relação entre o capital produtivo (P), o dinheiro (D) e a mercadoria (M):

Se considerarmos, por fim, D - M P M' - D' como forma especial do processo de circulação do capital, ao lado das outras formas a serem examinadas posteriormente, então ela se destaca pelo seguinte: 1) Aparece como ciclo do capital monetário, porque o capital industrial, em sua forma-dinheiro, como capital monetário, constitui o ponto de partida e o ponto de retorno de seu processo global. A própria fórmula expressa que o dinheiro não é aqui despendido como dinheiro, mas só adiantado; é, portanto, apenas formadinheiro do capital, capital monetário. Além disso, expressa que o valor de troca, não o valor de uso, é o fim último e determinante do movimento. Exatamente porque a figura monetária do valor é sua forma autônoma, palpável, de manifestação, a forma de circulação D D', cujo ponto de partida e ponto de chegada é o dinheiro real, expressa de modo mais palpável o motivo condutor da produção capitalista - o fazer dinheiro. O processo de produção aparece apenas como elo inevitável, como mal necessário, tendo em vista fazer dinheiro. Todas as nações de produção capitalista são, por isso,

\footnotetext{
${ }^{25}$ Vale mencionar a continuação da passagem de Marx: "o que aqui reina é unicamente Liberdade, Igualdade, Propriedade e Bentham. Liberdade! Pois comprador e vendedor de uma mercadoria, por exemplo, da força de trabalho, são determinados apenas por sua livre-vontade. Contratam como pessoas livres, juridicamente iguais. $\mathrm{O}$ contrato é o resultado final, no qual suas vontades se dão uma expressão jurídica em comum. Igualdade! Pois eles se relacionam um com o outro apenas como possuidores de mercadorias e trocam equivalente por equivalente. Propriedade! Pois cada um dispõe apenas sobre o seu. Bentham! Pois cada um dos dois só cuida de si mesmo. O único poder que os junta e leva a um relacionamento é o proveito próprio, a vantagem particular, os seus interesses privados." (MARX,1996 b, p. 144)
} 
periodicamente assaltadas pela vertigem de querer fazer dinheiro sem a mediação do processo de produção. 2) $\mathrm{O}$ estágio de produção, a função de $\mathrm{P}$, constitui, nesse ciclo, a interrupção das duas fases da circulação D - M M' D', que, por sua vez, são apenas mediações da circulação simples D - M - D'. $\mathrm{O}$ processo de produção aparece na forma do próprio processo de circulação formal e expressamente como aquilo que no modo de produção capitalista ele é, como simples meio de valorização do valor adiantado, portanto o enriquecimento enquanto tal é um fim em si mesmo da produção. (MARX, 1985, p. 43-44)

Embora o capital industrial constitua o ponto de partida e de retorno do processo de circulação de capital, há de se notar que o capital monetário tem certa proeminência: o processo de produção capitalista aparece, embora não seja só isso, como um processo de fazer dinheiro.

Ou seja, ao mesmo tempo em que isto não pode ser verdade, as formas de representação dos agentes da produção operam com este $\operatorname{suposto~}^{26}$. O processo de produção, desta maneira, ao mesmo tempo em que é o essencial tanto para a produção de mais-valor quanto para a acumulação de capital, aparece como um simples elo. Mostra-se só como um mal necessário. Tanto é assim, que os agentes da produção, e as próprias nações, segundo Marx, são seduzidos pelo ímpeto de se fazer dinheiro sem a mediação da produção; o poder privado e a pessoa privada, deste modo, operam em meio ao fetichismo do dinheiro. Este último, no limite, traz consigo a compulsão para que se tenha a produção pela produção - o valor de troca como fim do processo e o valor de uso aparecendo como algo meramente circunstancial -; ao mesmo tempo, porém, este processo aparece como seu oposto: um processo em que o acúmulo de dinheiro é somente o incremento no poder social do possuidor - seja ele quem for - destes títulos de curso forçado que representam a riqueza social. Vê-se, portanto, que o capital industrial, e com ele a produção capitalista de mercadorias, é o essencial para a conformação do modo de produção capitalista. A aparência do processo de troca, porém, traz o oposto; e, assim, a mediação recíproca entre capital produtivo, mercadorias e dinheiro oculta-se.

O livro II de $O$ capital trata justamente deste processo, que se conforma na reprodução ampliada e na realização do mais-valor na esfera da circulação. A conformação do capital e do trabalho produtivo, que são enfatizados no livro I, aparecem no livro II como pressupostos da produção capitalista de mercadorias. O ciclo do capital produtivo, deste modo, tem no dinheiro um elemento sem o qual a própria circulação não é possível; ao mesmo tempo, a mediação do modo específico pelo qual se dá a produção traz as determinações essenciais da produção capitalista de mercadorias, em que o dinheiro já tem uma grande autonomização e em que o

\footnotetext{
${ }^{26}$ Sobre as formas de representação e de apresentação em Marx, Cf. GRESPAN, 2019.
} 
complemento do fetichismo da mercadoria não é tanto o fetichismo jurídico, como quer Pachukanis, mas o fetichismo do dinheiro. Deste modo, complementa Marx sobre o capital industrial:

O ciclo do capital produtivo tem a fórmula geral: P M' - D' - M P. Significa a função periodicamente renovada do capital produtivo, portanto a reprodução, ou seu processo de produção como processo de reprodução com relação à valorização; não só produção, mas reprodução periódica de mais-valia; a função do capital industrial que se encontra em sua forma produtiva, não como função realizada uma única vez, mas como função periodicamente repetida, de modo tal que o reinicio seja dado pelo próprio ponto de partida. Uma parte de $\mathrm{M}^{\prime}$ pode reingressar diretamente em certos casos, em ramos de investimento do capital industrial como meio de produção no mesmo processo de trabalho do qual saiu como mercadoria; dessa maneira se evita apenas a transformação de seu valor em dinheiro real ou em signo monetário, ou só recebe expressão autônoma como moeda de conta. Essa parte do valor não entra na circulação. Assim, entram valores no processo de produção que não entram no processo de circulação. $\mathrm{O}$ mesmo vale para a parte de $\mathrm{M}^{\prime}$ que o capitalista consome como parte do mais-produto in natura. Esta é, no entanto, para a produção capitalista insignificante; precisa, no máximo, ser considerada na agricultura. (MARX, 1985, p. 49)

A reprodução do capital traz o processo de trocas como um elo intermediário no processo produtivo global, em que o momento preponderante está na esfera da produção imediata. (Cf. MARX, 2011) Com isso, o ciclo do capital produtivo tem como ponto de início e como ponto final a produção e, mais precisamente, a acumulação de capital. Trata-se da reprodução, não só das mercadorias, mas do mais-valor. A circulação e o processo de circulação são dependentes do processo de trabalho produtivo; e, assim, na análise do essencial do modo de produção capitalista, é o dinheiro que é um mero elo evanescente na produção; porém, na superfície da sociedade, o oposto parece ser verdadeiro. E, ao ler o livro II, percebe-se que o fetichismo do dinheiro coloca-se em ato, ao mesmo tempo, supondo a extração de mais-valor e a acumulação de capital e trazendo à tona uma forma de apresentação da forma dinheiro em que ela parece ser o central. E, por isso, como bem ressaltou Vinícius Casalino (2019) - embora possamos discordar de algumas de suas posições - a análise pachukaniana peca por considerar a conformação categoria pessoa (na figura do sujeito de direito) somente em correlação com a forma mercadoria. Ao passo que a forma dinheiro, que pressupõe algo muito mais avançado que a circulação simples (M-D-M), seria central já no livro I, Pachukanis parece trazer uma ênfase exagerada nos possuidores de mercadorias, deixando de lado um tratamento mais cuidadoso da mercadoria universal colocada no dinheiro. Pachukanis, assim, enfatiza - na esteira de Rubin (1980) - o fetichismo da mercadoria; e, com isso, traz à tona sua concepção 
de "fetichismo jurídico", ao invés de tratar da efetividade do fetichismo do dinheiro. Ao invés de ir ao fundo da leitura de $O$ capital, e, assim, compreender as complexas correlações entre as diferentes formas e figuras econômicas, tem-se uma ênfase no elemento jurídico. Veja-se: ele pode até mesmo ser importante na obra magna de Marx, mas precisa ser tratado em meio às metamorfoses da forma mercadoria em sua correlação com a autovalorização do valor.

Um dos aspectos que destaca a importância do livro II de $O$ capital está no modo como se articulam a reprodução ampliada do capital, o processo de circulação e o fetichismo do dinheiro. E, assim, também para o estudo do Direito em Marx, há de se trazer a diferença específica entre a troca de mercadorias que se dá na circulação simples, e nas sociedades précapitalistas em que se tem produção de mercadorias, da produção propriamente capitalista das mercadorias. Para isso, acreditamos, é importante passar, não só pelo capital industrial, mas pelo capital monetário.

\section{O Direito e autonomização das formas econômicas no livro II de $\mathbf{O}$ capital}

Tratar do Direito no livro II, pelo que dissemos, implica no reconhecimento dos nexos trazidos acima. De um lado, isto se dá porque não é possível tratar das citações marxianas fora de seu contexto. Porém, há de se reconhecer que a constituição do capital monetário no processo de circulação explica o modo pelo qual se coloca a esfera jurídica, ao mesmo tempo em que alguns elementos desta última - centrais no livro III (Cf. SARTORI, 2019 b, c), mas já presentes no livro II - podem ser de grande relevo para que se compreenda a natureza dúplice do capital monetário: autonomizado e dependente da esfera produtiva e das mercadorias. Também em meio a tal autonomização é que se colocam os distintos papéis cumpridos pelo Direito no processo de circulação do capital. Ele precisa ser tratado ao passar pelas formas econômicas abordadas em $O$ capital, bem como pelas figuras econômicas concretas (como os juros, o lucro e a renda) que, mesmo que dependentes destas formas, aparecem como se tivessem vida própria.

Deste modo, se, talvez, seja um pouco exagerada a posição segundo a qual o Direito é o elo essencial na conformação da sociabilidade capitalista ${ }^{27}$, não é descabido apontar que as

\footnotetext{
${ }^{27}$ Não concordarmos plenamente com Mascaro, para quem "a própria existência da forma jurídica constitui a sociabilidade capitalista: por direito, o capital é do capitalista, e não dos trabalhadores; e o são também por direito a prisão e a segregação dos indesejados; tudo que circula só se faz mediante deveres e obrigações. O mundo da mercadoria é jurídico; a equivalência a tudo preside. Não há outro direito que não o capitalista." (MASCARO, 2018, p. 63) A ênfase do autor no momento jurídico nos parece um tanto quanto exagerada; se é verdade que o Direito tem um papel de grande relevo nestes atos destacados por Mascaro, não se pode dizer que ele constitui a sociabilidade capitalista, ou que o mundo da mercadoria é jurídico. Tais identidades trazidas por Mascaro precisam ser meandradas, tendo-se em conta, dentre outras coisas, outras formas econômicas que aquela da mercadoria,
} 
formas jurídicas ${ }^{28}$, como o contrato, as transações jurídicas, as promessas negociais, a noção de justiça $^{29}$, a ficção jurídica, entre outras, vêm a desempenhar um papel de destaque na imediatidade da realidade efetiva da sociedade capitalista, tratada por Marx no livro III, mas já vislumbrada em alguns de seus aspectos no livro II. Ou seja, se é verdade que não se pode exagerar o papel real e efetivo que o Direito vem a exercer na conformação das determinações essenciais da relação-capital, igualmente verdadeiro é que a aparência das transações que se dão na sociedade capitalista, em grande parte, é constituída mediante, embora não só, a esfera jurídica. Marx já havia colocado no livro I que a economia está envolvida por relações jurídicas, mas “o conteúdo dessa relação jurídica ou de vontade é dado por meio da relação econômica mesma." (MARX, 1996 a, p. 79) Ele também diz no livro III que não se tem o essencial nas formas jurídicas, mas no conteúdo da relação jurídica, tendo-se uma peculiar dialética entre essência e aparência: “as formas jurídicas (jurisrichen Formen) em que essas transações econômicas aparecem como atos de vontade dos participantes, como expressões de sua vontade comum e como contratos" (MARX, 1986 a, p. 252) trazem à tona o modo fenomênico pelo qual as relações econômicas (nas diversas formas e figuras do capital) aparecem. Logo depois, ao tratar dos contratos, das transações jurídicas e das demais formas jurídicas, Marx complementa dizendo tratar-se daquelas "cuja execução pode ser imposta à parte individual por meio do Estado" e, assim, "não podem, como simples formas, determinar esse conteúdo. Elas apenas o expressam" (MARX, 1986 a, p. 252) ${ }^{30}$. Deste modo, dizer que "o mundo da mercadoria é jurídico" (MASCARO, 2018, p. 63) só é verdadeiro caso esteja-se referindo ao elemento mais imediato e fenomênico da sociabilidade capitalista; por mais que o Direito passe pela forma mercantil, como destaca corretamente Pachukanis (2017), as mediações para compreender a forma mercadoria não estão essencialmente no elemento jurídico, mas em outras formas

como o dinheiro, por exemplo. Também há de se apontar que o capital não é uma coisa, mas uma relação social, de modo que talvez fossem necessárias maiores mediações no modo pelo qual Alysson Mascaro traz certa centralidade do Direito.

${ }^{28}$ Usamos a expressão aqui no plural, e não no singular, como aparece em Pachukanis porque, no livro III em especial, Marx traz sempre tal categoria no plural, seja ao tratar da justiça, da renda ou dos juros.

${ }^{29}$ Sobre a noção de justiça em Marx, Cf. SARTORI, 2017 b.

${ }^{30}$ Contra Wagner, diz Marx: "mostrei na análise da circulação de mercadorias que no escambo desenvolvido as partes se reconhecem tacitamente como pessoas iguais e como proprietários dos respectivos bens a serem por eles trocados; eles já o fazem ao oferecer uns para os outros seus bens e ao entrar em acordo uns com os outros sobre o negócio. Essa relação fática que se origina primeiro na e através da própria troca adquire mais tarde forma jurídica no contrato etc.; mas essa forma não cria nem o seu conteúdo, a troca, nem a relação nela existente das pessoas entre si, mas vice-versa." (MARX, 2017, p. 273) Há de se notar que, aqui, Marx retoma o tema do segundo capítulo do livro I de $O$ capital, bastante enfatizado por Pachukanis. Percebe-se também que o que destacamos aqui também é bastante claro. 
econômicas, como a forma dinheiro e a forma capital, tendo-se a compreensão do mundo das mercadorias ainda que remeter às figuras econômicas - como os juros, a renda e o lucro - que aparecem na imediatidade da sociedade. Novamente, o essencial aparece, não tanto na compreensão da relação entre o fetichismo da mercadoria e o jurídico, mas, no que passa pelo livro II, na correlação entre o fetichismo da mercadoria e o fetichismo do dinheiro, visto em ato.

As figuras econômicas concretas tratadas na análise do processo global de produção, como os juros, a renda, o lucro, têm sua repartição, em grande parte, presidida pelo movimento da propriedade privada, que é reconhecida juridicamente pelo Estado, sendo o Direito um mediador essencial na distribuição do mais-valor (Cf. GRESPAN, 2011; SARTORI, 2019 b, c). Estas figuras, por sua vez, têm uma correlação íntima com as formas econômicas tratadas no livro I (mercadoria, dinheiro, capital, por exemplo), ao mesmo tempo em que, também por meio do Direito, são autonomizadas por meio de títulos e promessas cujo reconhecimento se dá juridicamente $^{31}$. A autonomização destas figuras econômicas, porém, constitui-se, não primordialmente como uma relação jurídica, mas em meio às contradições que marcam as relações econômicas do modo de produção capitalista; para que sejamos mais diretos: por meio de formas jurídicas, opera-se em meio a tais figuras econômicas, mas o seu conteúdo não é determinado pelo Direito ou pelas formas jurídicas, mas pelo imbrincado processo econômico $^{32}$. Assim, a ênfase de Pachukanis no momento jurídico - e não na dialética peculiar entre as formas e as figuras econômicas presentes nos livros de $O$ capital - corre o risco de tomar o reconhecimento jurídico e estatal da propriedade privada pela existência factual desta

\footnotetext{
${ }^{31}$ Veja-se Marx sobre os juros: "como o juro somente nasce do processo de produção, e seu resultado e tem de ser produzido, é o juro apenas um direito a uma parte de um trabalho excedente que ainda deve ser prestado, título a trabalho futuro, pretensão a uma parte do valor de mercadorias ainda não existentes. É portanto somente o resultado de um processo de produção em curso, durante um certo tempo, no termino do qual expiara." (MARX, 1982, p. 224)

${ }^{32}$ Trazer as formas jurídicas como determinantes seria trazer uma espécie de inversão, tal qual a da religião, que coloca os homens como criaturas divinas ao passo que Deus que é criado pelos homens. Não é por menos que Marx aponta certa correlação entre Direito e religião: "Este tecnicismo exagerado do Direito antigo mostra que a jurisprudência é uma pluma do mesmo pássaro que as formalidades religiosas.” (MARX, 1988, p. 281) Engels vai ainda mais longe e diz que "tratava-se da secularização da visão teológica. O dogma e o direito divino eram substituídos pelo direito humano, e a Igreja pelo Estado. As relações econômicas e sociais, anteriormente representadas como criações do dogma e da Igreja, porque esta as sancionava, agora se representam fundadas no direito e criadas pelo Estado. Visto que o desenvolvimento pleno do intercâmbio de mercadorias em escala social - isto é, por meio da concessão de incentivos e créditos - engendra complicadas relações contratuais recíprocas e exige regras universalmente válidas, que só poderiam ser estabelecidas pela comunidade - normas jurídicas estabelecidas pelo Estado -, imaginou-se que tais normas não proviessem dos fatos econômicos, mas dos decretos formais do Estado. Além disso, uma vez que a concorrência, forma fundamental das relações entre livres produtores de mercadorias, é a grande niveladora, a igualdade jurídica tornou-se o principal brado de guerra da burguesia." (ENGELS, KAUTSKY, 2012, pp. 17-18)
} 
última. Já havia dito Marx na Miséria da filosofia que "o Direito nada mais é que o reconhecimento oficial do fato" (MARX, 2004, p. 84) ${ }^{33}$. Depois, em uma passagem bastante citada por Pachukanis, Marx ainda aponta que na troca de mercadorias, os guardiões das mercadorias devem "reconhecer-se reciprocamente como proprietários privados." (MARX, 1996 a, p. 79) E, assim, no Direito tem-se uma relação entre fato e reconhecimento que não pode ser deixada de lado em hipótese alguma (Cf. LUKÁCS, 2013). Isto, em verdade, não ocorre no autor da Teoria geral do Direito e o marxismo; porém, alguns de seus seguidores não deixam de incorrer em algo do gênero e, deste modo, exacerbam a importância do Direito, tanto na obra de Marx quanto na própria compreensão do modo de produção capitalista; por vezes, tomam o reconhecimento jurídico como se constituísse, por si, os fatos econômicos; e, assim, em verdade, o mundo das mercadorias pode até mesmo ser reconhecido oficial e estatalmente por meio do Direito. Mas, nunca, ele "é" jurídico. Tal análise, que consideramos equivocada, se dá, em grande parte, por certa ênfase na leitura pachukaniana e em uma leitura um tanto quanto parcial do livro I de $O$ capital. Por isso também, acreditamos, é importante trazer à tona uma pequisa que enfoque nos diversos níveis de abstração e da exposição do texto marxiano, tendo-se cuidado para não trazer a relação entre Direito e mercadoria como se a forma mercantil fosse a única que desse uma base real ao Direito e como se a real compreensão da forma mercadoria decorresse de elementos jurídicos, e não econômicos.

Para o que aqui nos diz respeito mais diretamente, devemos destacar que, já no livro II, há certo afastamento da exposição de Marx diante do capital produtivo, tendo-se, em alguns momentos, o capital monetário e o comercial, e não o industrial, em destaque; a função do Direito neste livro de $O$ capital reflete este simultâneo afastamento e indissociabilidade entre a esfera da produção de mais-valor e a circulação, em que o mais-valor pode ser ou não realizado.

Neste âmbito tem-se que o modo pelo qual o capital monetário opera passando por títulos de propriedade que têm uma função bastante concreta no processo de circulação, mas que podem ou não voltar-se do modo produtivo à produção capitalista de mercadorias. Assim, tem-se um elemento essencial para a compreensão das crises capitalistas passando também pelo Direito: a duplicidade que se coloca entre o mundo das mercadorias e os títulos que representam a riqueza produzida de modo capitalista. Aqui, não poderemos tratar disso com todo o cuidado. Porém, devemos destacar sobre as transações jurídicas que, como diz Marx no livro III, "sem

\footnotetext{
${ }^{33}$ Para uma análise detida da questão, Cf. LUKÁCS, 2013.
} 
dúvida, essas transações são efetivamente determinados pelos refluxos reais. Mas isso não aparece na própria transação.” (MARX, 1986 a, p. 262) Nelas, assim, “o verdadeiro movimento circulatório do dinheiro como capital é, portanto, pressuposto da transação jurídica" (MARX, 1986 a, p. 263) de tal maneira que ela "é uma transação jurídica, que nada tem a ver com o processo real de reprodução, mas apenas o encaminha” (MARX, 1986 a, p. 262). Com isso, tem-se que a compreensão do Direito em Marx (mas em especial no livro II de $O$ capital) passa pelo entendimento dos meandros, não tanto das transações jurídicas, mas do movimento circulatório do capital e do processo real de reprodução, que aparecem como supostos no livro III (de onde tiramos as passagens acima), mas que são explanados no livro II, em que devemos enfatizar certa centralidade do capital monetário, que já traz consigo o caráter acentuado da duplicidade que rapidamente mencionamos.

Se se considera a coisa como ela se verifica na realidade, então o capital monetário latente que é acumulado para uso posterior consiste em: 1) Depósitos em bancos: e é uma soma de dinheiro relativamente reduzida da qual o banco realmente dispõe. Aqui a acumulação de capital monetário é apenas nominal. O que realmente está acumulado são créditos monetários, que só são conversíveis em prata à medida que chegam a ser convertidos em prata porque ocorre um equilíbrio entre o dinheiro sacado e o dinheiro depositado. $\mathrm{O}$ que se encontra como dinheiro nas mãos do banco é apenas uma soma relativamente pequena. 2) Títulos públicos. Estes não são capital ao todo, mas meros créditos sobre o produto anual da nação. 3) Ações. À medida que não constituem fraude, são títulos de propriedade sobre um capital real pertencente a uma corporação e de direito sobre a mais-valia que dele flui anualmente. (MARX, 1985, pp. 256-257)

Marx sempre destaca o uso futuro do capital monetário, que está sempre em relação indissolúvel com a esfera produtiva e, como já destacamos, com a acumulação de capital, que, por sua vez, necessita do incremento da produção. A natureza dúplice do capital monetário se liga à sua existência, por vezes, fictícia ${ }^{34} \mathrm{e}$ nominal, que se contrapõe àquilo que ele representa, a “imensa coleção de mercadorias" (MARX, 1996 a, p. 165), de que fala Marx no livro I. Ele aparece como crédito, como expectativa de apropriação da riqueza, ao mesmo tempo em que isto só se dá - ao menos na época de Marx - com uma base metálica, no caso acima, a prata ${ }^{35}$.

\footnotetext{
${ }^{34}$ Marx tratará no livro III dos títulos do governo que, por vezes, não têm lastro direto algum na materialidade da realidade efetiva, constituindo-se como capital fictício (Cf. MARX, 1986 a, b).

${ }^{35}$ Marx, porém, menciona, ainda no livro I, os títulos de crédito, que se colocariam mediante uma espécie de titularidade jurídica de direito privado: "apenas ao vencer o prazo fixado para o pagamento, o meio de pagamento entra realmente em circulação, isto é, ele passa realmente das mãos do comprador para as do vendedor. O meio circulante converteu-se em tesouro, ao interromper o processo de circulação em sua primeira fase ou ao ser subtraída da circulação a forma transformada da mercadoria. O meio de pagamento entra na circulação, porém depois que a mercadoria já se retirou dela. $\mathrm{O}$ dinheiro já não media o processo. Ele o fecha de modo autônomo, como existência absoluta do valor de troca ou mercadoria geral. $\mathrm{O}$ vendedor converte sua mercadoria em dinheiro
} 
Ao se tratar dos títulos públicos, nota-se: estes também se mostram como créditos ligados à produção futura de uma determinada nação; trata-se, tal qual no caso das ações, de um montante de dinheiro que, operando como capital, é adiantado para que a produção de mais-valor possa se dar; e, assim, com a posterior circulação do capital, os titulares do crédito se apropriam da riqueza, ou melhor dizendo, de uma parcela desta que se coloca para além daquela necessária à reprodução do capital. Isto acontece tendo-se - nas figuras concretas do processo global de produção, como os juros, a renda, o lucro - a apropriação social, por meio da titularidade da propriedade, de parcelas distintas do mais-valor. Esta apropriação é social ao passo que a apropriação - que passa pela figura da propriedade - é privada.

Para que coloquemos algo que diz respeito mais diretamente ao nosso tema: aqui, no livro II, o Direito, por meio da propriedade privada, não tem um papel proeminente na produção do mais-valor. Se Pachukanis, juntamente com a linhagem de autores que o segue, aponta a esfera jurídica como essencial na extração do mais-valor, aqui, vê-se algo distinto: o direito sobre parcela do mais-valor que flui na produção de uma sociedade por ações, bem como nos rendimentos bancários, dos títulos do governo ou da terra, implica, não no papel central do elemento jurídico na produção, mas para um papel bastante mediado e complexo na distribuição do mais-valor. Ou seja, o Direito, sob este aspecto, passa longe de constituir a sociabilidade capitalista, como quer Mascaro (2018); ele a toma como suposta e opera na superfície desta sociedade, tendo como pressupostos tanto o movimento circulatório do capital quanto o processo real de reprodução, que, como já dissemos, passa pela acumulação de capital. Tem-se também outra implicação bastante importante para o estudo do Direito em Marx (e, acreditamos, na sociedade capitalista): o direito sobre parcelas do mais-valor, que menciona Marx ao tratar da relação entre o capital monetário colocado nas sociedades por ações e o capital real de uma corporação, não passa tanto pela troca equivalente da circulação simples, mas pelo papel do Direito na distribuição do mais-valor no processo global de produção; neste último a titularidade da propriedade privada dá direito a parcelas da riqueza social, produzida na produção capitalista de mercadorias. E isto se dá, não na equivalência dos papéis dos

para satisfazer a uma necessidade por meio do dinheiro, o entesourador, para preservar a mercadoria em forma de dinheiro, o comprador que ficou devendo, para poder pagar. Se não pagar, seus bens são vendidos judicialmente. A figura de valor da mercadoria, dinheiro, torna-se, portanto, agora um fim em si da venda, em virtude de uma necessidade social que se origina das condições do próprio processo de circulação. O comprador retransforma dinheiro em mercadoria antes de ter convertido mercadoria em dinheiro ou realiza a segunda metamorfose da mercadoria antes da primeira. A mercadoria do vendedor circula, mas realiza seu preço somente sob a forma de um título de crédito de direito privado.” (MARX, 1996 a, p. 256) 
possuidores de mercadorias (como em Pachukanis, que enfatiza a figura do sujeito de direito), mas ao se ter como central funções bastante distintas dos agentes da produção, cuja posição aparece no processo de circulação de mercadorias de modo bastante diferenciado e explícito. Trata-se de algo colocado sobre o sistema capitalista da apropriação, que supõe a propriedade privada. Mas os proprietários sequer aparecem como indiferenciados. O proprietário do dinheiro diferencia-se substancialmente do proprietário da mercadoria força de trabalho, por exemplo. O dinheiro, é verdade, é um grande nivelador, mas o desenvolvimento do capital monetário pressupõe uma divisão do trabalho que ultrapassa em muito aquela visível na equivalência inicialmente colocada nas trocas mercantis, de tal modo que este nivelamento se dá entre os proprietários de dinheiro, e não é expandido de modo indiferenciado na sociedade. E, assim, as formas econômicas do dinheiro e do capital, bem como as figuras dos juros, da renda, e do lucro, por exemplo, supõem o direito que se coloca na troca de mercadorias (e essencialmente na compra e venda da mercadoria força de trabalho), mas também trazem à tona o reconhecimento da diferenciação entre os distintos tipos de proprietários que operam em meio ao processo de circulação do capital. Neste nível de abstração, portanto, a análise de Marx é bastante diferente daquela de Pachukanis.

A acumulação e a reprodução do capital, portanto, passam pelas trocas equivalentes, analisadas por Marx principalmente no capítulo II do livro I de $O$ capital. Porém, não se pode ficar somente neste nível de abstração. No que, novamente, tem-se o aspecto dúplice mencionado. Isto se dá tanto no capital monetário quanto nos direitos a ele conectados: no caso das sociedades por ações, a parcela dos lucros das empresas depende da produção deste lucro mesmo (que tem dependência tanto dos preços de custo quanto, de modo mais basilar, da produção de mais-valor); nos títulos do governo, há os créditos sobre o produto anual de uma nação. $\mathrm{O}$ aspecto dúplice se mostra quando a relação entre o capital monetário e o industrial remete às diversas incertezas do processo produtivo. Os direitos a apropriação, assim, operam ao passo que tais créditos sempre podem adquirir uma característica de mera ficção ${ }^{36}$. No livro II, e principalmente no livro III (Cf. SARTORI, 2019 b, c), tal aspecto dúplice do capital monetário ganhará destaque, não sendo pequeno o papel das formas jurídicas na constituição do direito à apropriação de parcelas do mais-valor. Ao mesmo tempo, pelo que notamos aqui, em Marx, o essencial não é o modo pelo qual operam as formas jurídicas na distribuição do mais-valor, mas a maneira pela qual a autonomização das figuras econômicas (lucro, renda,

\footnotetext{
${ }^{36}$ No livro III, ao tratar da renda, Marx desdobrará a questão remetendo à ficção jurídica. Cf. MARX, 1986 a, b.
} 
juros, por exemplo) permite que a apropriação da riqueza se dê na efetividade da sociedade. E, assim, chega-se a uma conclusão essencial ao nosso tema: para tratar seriamente do Direito em Marx, tal relação entre mercadorias e dinheiro, e entre o capital industrial e o capital monetário é de grande relevo. E, é preciso que isto seja dito: Pachukanis, e seus seguidores, não chegam a aprofundar este aspecto, trazendo como principal elemento de suas análises a relação entre a forma mercadoria e aquilo que ele chama de forma jurídica, relação esta que estaria presente principalmente do primeiro ao terceiro capítulos do livro I de $_{\text {capital }}{ }^{37}$.

O Direito é, em verdade, um elo importante nesta correlação entre capital produtivo e improdutivo, bem como na distribuição do mais-valor; ele opera tal relação, ao mesmo tempo que o essencial nela é a divisão do trabalho que se coloca no seio da relação-capital mesma e que dá ensejo às distintas figuras econômicas, como os juros, a renda, o lucro, etc; mesmo que o momento jurídico não seja o elemento central - este último passa pela própria constituição objetiva das formas econômicas, e de sua relação com as figuras econômicas concretas - ele é um elemento da constituição concreta e efetiva da distribuição da riqueza, mediante a propriedade, no capitalismo. E isso, como já dissemos, significa que o aspecto jurídico é essencial na operacionalização das relações econômicas, mas as formas jurídicas não podem determinar o conteúdo destas relações.

Marx é bastante claro o dizer que o Direito não pode determinar este processo, como querem os socialistas vulgares (Cf, MARX, $1986 \mathrm{a}, \mathrm{b})^{38}$. Ao mesmo tempo, ele não deixa de destacar como que se opera na efetividade da sociedade capitalista por meio de contratos, transações jurídicas, promessas de crédito, ficções jurídicas, etc. No que, também sob este aspecto, há uma correlação entre o processo de produção do mais-valor e a circulação do capital, entre os agentes da produção, o Direito e os agentes da circulação. Marx traz algo importante sobre este ponto ao destacar a relação entre a circulação de mercadorias, a sua produção e a distribuição da riqueza social:

Os agentes da circulação precisam ser pagos pelos agentes da produção. Mas se os capitalistas, que compram e vendem entre si, não criam produtos nem valor, isso não se altera quando o volume de seu negócio os capacita e obriga

\footnotetext{
${ }^{37}$ Sobre este ponto, Vinícius Casalino (2019) traz uma crítica decisiva a Pachukanis. Diz o autor brasileiro que o autor da Teoria geral do Direito e o marxismo sequer é coerente com a análise do livro I, pois permanece ligado à circulação simples, e não leva em conta sequer a autonomização da forma dinheiro. Diz-se que "não parece exagero afirmar que o autor russo concentra esforços nos três primeiros capítulos de $O$ capital, isto é, analisa a exposição da forma mercantil e da circulação simples de mercadorias, mas relega a segundo plano a ressignificação que tais categorias experimentam quando entra em cena a circulação do dinheiro como capital." (CASALINO, 2019, p. 2884)

${ }^{38}$ Para uma análise desta crítica de Marx, Cf. SARTORI, 2019 b.
} 
a transferir essa função a outros. Em vários negócios, compradores e vendedores são pagos por meio de uma porcentagem do lucro. A frase de que são pagos pelos consumidores não ajuda em nada. Os consumidores só podem pagar à medida que eles mesmos, como agentes da produção, produzem para si um equivalente em mercadorias ou se apropriam de tal equivalente dos agentes da produção, seja mediante direito legal como seus associés etc.!, seja mediante serviços pessoais. (MARX, 1985, p. 311)

Ao se ter em conta a reprodução ampliada do capital, a correlação entre capital produtivo e improdutivo vem à tona na medida em que na circulação realiza-se o mais-valor, mas este último não é produzido nesta esfera. Assim, de certo modo, são os agentes da produção que pagam os da circulação. A divisão do trabalho que se coloca no capitalista coletivo (Cf. MARX, 1986 a, b) na grande indústria faz com que as diferentes funções na reprodução social sejam executadas, não mais pelo mesmo agente, mas por agentes distintos. Assim, o lucro é uma parcela do mais-valor e, posteriormente, uma parcela deste lucro coloca-se como um custo ao agente da produção, que precisa dos agentes da circulação para que seja possível o consumo das mercadorias produzidas.

Marx é explícito sobre tal relação: não é verdade que ambos, agentes da produção e da circulação, sejam pagos pelos consumidores; em verdade, apesar das aparências, o incremento da riqueza não está na esfera da circulação de mercadorias, mas na produção capitalista de mercadorias, que, real e efetivamente, supõe a acumulação de capital ${ }^{39}$. O capital produtivo, de imediato $^{40}$, paga o improdutivo, trazendo nisto, ao mesmo tempo, o incremento da produtividade que decorre da divisão do trabalho e custos decorrentes deste incremento. De outro lado, porém, há de se perceber que, na reprodução do capital, os consumidores só podem consumir na medida em que, ou são eles mesmos agentes da produção (trabalhadores ou capitalistas) ou se apropriam de um equivalente em dinheiro (ou crédito) àquilo produzido pelos agentes da produção. Assim, nota-se que, na reprodução do capital há uma importante correlação a ser trazida à tona entre capital produtivo e improdutivo. E, perceba-se: nela, não é só pelo trabalho que se apropria da riqueza social, mas também mediante a titularidade jurídica

\footnotetext{
${ }^{39}$ Remetendo ao Direito, diz Marx no livro I: “os representantes consequentes da ilusão de que a mais-valia se origina de um aumento nominal de preço ou do privilégio do vendedor de vender a mercadoria caro demais pressupõem, portanto, uma classe que só compra sem vender, por conseguinte, só consome sem produzir. A existência de tal classe é, do ponto de vista alcançado por nós até agora, o da circulação simples, ainda inexplicável. Mas antecipemo-nos. O dinheiro, com que tal classe continuamente compra, deve fluir continuamente dos próprios possuidores de mercadorias, sem intercâmbio, gratuitamente, por quaisquer títulos de direito e poder." (MARX, 1996 a, p. 280-281)

${ }^{40}$ De imediato porque isto, claro, depende da produção de mais-valor, sendo a noção de custos de produção decorrente da atividade dos agentes da produção, ao mesmo tempo em que não se sustenta em si mesma, mas na produção de mais-valor. (Cf. SARTORI, 2019 b, c)
} 
de parcelas da produção futura. Vê-se, assim, que o Direito, no livro II, tem uma função importante no sistema de apropriação capitalista.

Em meio a esta divisão, a função dúplice do capital monetário se coloca real e efetivamente. Marx diz que a apropriação deste equivalente pode ser dar mediante serviços pessoais, por exemplo, ao se vender a força de trabalho. Mas pode dar-se também por meio de direitos legais, como aqueles de um associado, por exemplo ${ }^{41}$. Ou seja, pode-se destacar aqui um modo de aquisição de propriedade que se relaciona à produção na medida em que ao trabalho é dado um equivalente em dinheiro. Porém, tem-se também o recebimento de dinheiro que não depende do trabalho, mas da titularidade de um direito, como no caso da renda, dos juros, e nas sociedades por ações. E, sobre este ponto, é preciso que enfatizemos a diferença específica entre um caso e outro.

No primeiro caso, tratado sobretudo no livro I de $O$ capital, não há "injustiças" "42, mas o processo capitalista de trabalho, em que "o capitalista comprou a força de trabalho pelo seu valor de 1 dia. A ele pertence seu valor de uso durante uma jornada de trabalho. Obteve assim o direito de fazer o trabalhador trabalhar para ele durante 1 dia" (MARX, 1996 a, p. 345-346). Trata-se daquilo que, em grande parte corretamente, é destacado por Pachukanis (2017). No entanto, o outro lado da moeda é muito distinto: tem-se a apropriação do mais-valor que foi produzido pelos agentes da produção, mais precisamente pelo trabalho produtivo (Cf. COTRIM, 2013); esta apropriação se deve à titularidade de uma ação ou de uma cota da corporação. E, assim, a distribuição do mais-valor não se dá somente ao se ter em conta o equivalente de trabalho, como no livro I, mas ao se ter em conta a propriedade privada e sua titularidade (Cf. GRESPAN, 2011, 2019). Neste sentido, há, até certo ponto, um divórcio entre a função exercida na produção e a propriedade decorrente desta $^{43}$ : a partir do momento em que é essencial ao capital o incremento da divisão do trabalho para a acumulação de capital - na grande indústria, para ser mais preciso - a correlação entre capital produtivo e improdutivo é conformada a partir dos meandros da produção capitalista de mercadorias, mas tem no momento

\footnotetext{
${ }^{41}$ No livro III, Marx trata de trocas que não são exatamente equivalentes e em cujo preço estão arbitrariedades; estas últimas, por sua vez, também passam pela mediação do Direito. (Cf. SARTORI, 2019 b, c)

${ }^{42}$ Aponta Marx que "o valor de uso da força de trabalho, o próprio trabalho, pertence tão pouco ao seu vendedor, quanto o valor de uso do óleo vendido, ao comerciante que o vendeu. O possuidor de dinheiro pagou o valor de um dia da força de trabalho; pertence-lhe, portanto, a utilização dela durante o dia, o trabalho de uma jornada. A circunstância de que a manutenção diária da força de trabalho só custa meia jornada de trabalho, apesar de a força de trabalho poder operar, trabalhar um dia inteiro, e por isso, o valor que sua utilização cria durante um dia é o dobro de seu próprio valor de um dia, é grande sorte para o comprador, mas, de modo algum, uma injustiça contra o vendedor" (MARX, 1996 a, p. 311). Sobre a questão da justiça em Marx, Cf. SARTORI, 2017 b.

${ }^{43}$ Para uma análise desta questão, Cf. SARTORI, 2019 c.
} 
jurídico algo importante para a distribuição do mais-valor.

O Direito, assim, tem uma função importante no modo pelo qual os agentes da produção e da circulação se relacionam. Porém, como já dissemos, isto remete sempre ao solo da produção que, por sua vez, determina a relação estabelecida entre as diversas formas e figuras econômicas. O direito à apropriação de uma cota do lucro futuro de determinada empresa, por exemplo, só consegue ser efetivo diante de uma proporção correta entre os diferentes departamentos (I e II) da economia capitalista. Sem a produção de meios de produção (c) para determinada quantidade de assalariados (v), o consumo, por exemplo, fica prejudicado na medida em que estes trabalhadores acabam não sendo empregados na produção. Sem trabalhadores para abundantes meios de produção, estes últimos ficam ociosos também. No livro II Marx trata disto e, para nosso tema, é preciso que se diga que o direito de apropriar-se de parcela da riqueza tem relação com isto:

Ou a massa dos meios de produção precisa ser suficiente para absorver a massa de trabalho, para ser transformada em produto por intermédio dela. Caso não houvesse meios de produção suficientes, então o trabalho excedente de que o comprador dispõe não seria utilizável; seu direito de dispor dele não levaria a nada. Caso houvesse mais meios de produção do que trabalho disponível, então não seriam saturados de trabalho, não seriam transformados em produto. (MARX, 1985, p. 311)

Note-se como que o essencial para Marx não está no direito à apropriação do fruto do trabalho excedente, mas na possibilidade mesmo de este trabalho excedente produzir maisvalor. Se é verdade que este direito a se apropriar do produto decorrente do tempo de trabalho é importante para que se perceba como que o Direito reconhece as bases da relação-capital, há de se ir além deste ponto. A função do Direito não está somente na correlação entre a produção capitalista de mercadorias, a força de trabalho e produção de mais-valor; tem-se também uma dimensão importante da esfera jurídica que se coloca quando aos direitos e ao título de propriedade não necessariamente correspondem, de imediato, equivalentes. No caso que aqui tratamos, isto pode se dar na medida em que há uma desproporção entre capital constante (c) e capital variável (v); isto também pode se dar ao passo que a produção de meios de produção (departamento II) está em descompasso com a produção de bens de consumo (departamento I). Ou seja, aquilo que propicia a real apropriação da riqueza não é o direito a uma cota desta, mas o processo econômico subjacente à apropriação da riqueza, que é operada por meio destes direitos. Assim, a natureza dúplice do capital monetário - essencial para o processo de circulação do capital - se mostra ao passo que aos títulos de propriedade, aos créditos e às expectativas decorrentes imediatamente das formas jurídicas pode ou não corresponder uma 
riqueza real. Tal elemento é essencial para o tratamento das crises comerciais e financeiras, por exemplo (Cf. FOSTER; MAGDOFF, 2009). E, na esteira do que estamos colocando neste texto, podemos dizer: o essencial para a compreensão destas crises está no entendimento da reprodução ampliada do capital, da queda tendencial da taxa de lucro, na correlação entre as formas e as figuras econômicas, em suma, na contradição entre o desenvolvimento das forças produtivas e as relações de produção. Porém, não há como negar que a análise do Direito em Marx, e no capitalismo, passe por esta natureza dúplice do capital monetário. Em um nível mais concreto de abstração que aquele do livro I não se tem só a relação entre o Direito e a forma mercantil, mas também o modo pelo qual a forma dinheiro, trazida à tona no capital monetário, traz consigo aspectos de grande relevo para a crítica ao Direito e ao capitalismo.

O papel do Direito diante das figuras concretas do capital só pode ser tratado no livro III. No entanto, podemos notar também no nível de abstração do livro II que ele é bastante importante nesta seara. Para o que nos diz respeito mais diretamente, devemos destacar que este aspecto já é preparado por Marx, até certo ponto, em suas determinações ligadas à reprodução do capital, no livro II. Neste último livro, as formas mais simples do capital monetário têm destaque, ao passo que, com a mediação do fetichismo do dinheiro, ao tratar do processo global de produção, as figuras mais irracionais do capital ganham destaque posteriormente, no livro III, com o capital portador de juros e a renda. Em meio a estes, em oposição ao entesouramento e ao reinvestimento na produção, tem-se o capital monetário colocado em relação à produção futura e correlacionado a títulos jurídicos e documentos legais, que podem ou não ser fruto de fraude, da especulação, etc. Isto, porém, não pode ser tratado neste momento. Fica, porém, a importância do capital monetário no processo de circulação, como vimos, relacionado à reprodução e à acumulação de capital.

Deste modo, diz Marx sobre o capital monetário e suas diversas figuras:

A forma mais simples em que esse capital monetário latente adicional pode apresentar-se é a de tesouro. E possível que esse tesouro seja ouro ou prata adicionais, obtido direta ou indiretamente no intercâmbio com os países que produzem metais nobres. E só desse modo cresce de maneira absoluta o tesouro monetário dentro de um país. Por outro lado, é possível - e esta é a maioria dos casos - que esse tesouro seja apenas dinheiro retirado da circulação interna que, na mão de capitalistas individuais, assumiu a forma de tesouro. Além disso, é possível que esse capital monetário latente consista apenas em signos de valor - aqui ainda fazemos abstração do dinheiro creditício -, ou também em meros direitos constatados por documentos legais, títulos jurídicos! do capitalista contra terceiros. Em todos esses casos, qualquer que seja a forma de existência desse capital monetário adicional, ele representa, à medida que é capital in specie apenas títulos jurídicos adicionais, 
mantidos em reserva por capitalista, sobre a produção anual adicional, futura, da sociedade. (MARX, 1985, pp. 238-239)

O entesouramento, na efetividade da sociedade capitalista, é muito incomum. Tem-se, em geral, a necessidade de empréstimos e, assim, cria-se uma dependência do capital produtivo diante do capital portador de juros (Cf. MARX, $1986 \mathrm{a}, \mathrm{b}$ ). Ao passo que o tesouro representaria a retirada do capital monetário de circulação em forma de dinheiro para futuro investimento, ou o acúmulo de metais preciosos, algo distinto se dá quando o capital monetário aparece como mero signo de valor.

Para o que nos diz respeito aqui, deve-se destacar que, neste caso, a expectativa do direito a apropriação se coloca como central. Documentos legais e títulos jurídicos aparecem como o meio pelo qual é possível operacionalizar a apropriação da riqueza social. E, assim, as transações jurídicas aparecem como o elo intermediário entre a produção futura de mais-valor e a apropriação de parcela deste mais-valor, que pode ou não ser efetivamente produzido. Neste sentido, percebe-se, novamente como que o capital monetário, também por meio do Direito, intervém no processo de circulação do capital estabelecendo um liame entre o capital produtivo e o improdutivo, e pode ser importante para a análise das crises. Para a compreensão do Direito em $O$ capital, portanto, não basta a forma mercadoria; é preciso tratar, percebe-se pela análise do livro II, também da forma dinheiro. A função do Direito no processo imediato de produção precisa ser vista ao se ter em conta também a reprodução e a acumulação de capital e, portanto, não só o capital industrial, mas sua relação com o capital monetário no processo de circulação. Claro, ainda seria preciso analisar a função do Direito em meio às figuras econômicas como juros, renda, lucro; no entanto, isto - que também não foi abordado por Pachukanis - envolve uma análise detalhada do livro III. Se, em parte, isto já foi iniciado (Cf. SARTORI, 2019 b, c), ainda é preciso que se escave com cuidado $O$ capital de Marx em sua totalidade. Ele vem sendo enfatizado somente de modo parcial, principalmente, por meio de uma visão pachukaniana do livro I e isto precisa se modificar.

\section{Apontamentos finais}

O estudo do livro II de $O$ capital propicia que a contraditoriedade da sociedade capitalista possa ser enxergada, também, no que diz respeito ao Direito. No livro I, a gênese e a conformação das principais formas econômicas do modo de produção capitalista se explicitam, chegando, ao fim do livro ao processo pelo qual abre-se espaço para a supressão da própria relação-capital. Este processo, claro, se explicita ao se analisar o papel do Direito 
também: vai-se da função que este tem na compra e venda da força de trabalho por meio da vontade livre, passa-se pelo modo pelo qual a luta pela diminuição da jornada de trabalho redunda na limitação desta vontade - então, os "trabalhadores têm de reunir suas cabeças e como classe conquistar uma lei estatal, uma barreira social intransponível, que os impeça a si mesmos de venderem a si e à sua descendência, por meio de contrato voluntário com o capital, à noite e à escravidão!" (MARX, 1996 a, p. 414) - e se chega, por fim, ao modo pelo qual, depois de analisar o papel das legislações sanguinárias na assim chamada acumulação primitiva, não são as reivindicações jurídicas a subverter as relações de produção; antes, trata-se "da expropriação de poucos usurpadores pela massa do povo" (MARX, 1996 b, p. 381). Para os nossos propósitos neste artigo, há dois pontos a serem destacados: primeiramente, há de se apontar que Pachukanis vem a enfatizar com cuidado somente o primeiro elemento que destacamos no livro I. E, assim, até mesmo esta parte da obra de Marx precisa de uma investigação mais cuidadosa. Em segundo lugar, podemos destacar que, no livro II, ao tratar do "sistema de apropriação capitalista" (MARX, 1996 b, p. 381), Marx começa a mostrar como que a propriedade privada - antes vista como decorrente do trabalho, ou da apropriação da força de trabalho por meio da relação social de assalariamento - passa a ter uma correlação bastante mais mediada com o trabalho. Pelo que vimos, é possível se apropriar da riqueza social em correlação com o capital produtivo. Porém, o capital monetário - na figura dos agentes da circulação e que é essencial ao processo de circulação, à reprodução e à acumulação de capital - é remunerado, de certo modo, não devido à produtividade do seu trabalho, mas a partir de parcelas da riqueza produzida pelos agentes da produção, envolvidos no processo de trabalho. Ou seja, o próprio processo mediante o qual há ganho de produtividade com a divisão do trabalho entre entre capital industrial, comercial e monetário faz com que o princípio burguês de repartição da riqueza (o quantum de trabalho) seja imediatamente negado. A apropriação do mais-valor passa a se dar, não tanto de acordo com o trabalho dos agentes econômicos, mas em função da titularidade da propriedade. Por mais que isto se dê de modo bastante mediado - até mesmo porque, por vezes, não é possível saber se a produção efetivamente produzirá maisvalor, ou se haverá equilíbrio entre capital constante (c) e variável (v), ou se há equilíbrio entre os departamentos que produzem bens de produção (II) ou de consumo (I) - há uma negação, dentro do próprio capitalismo, do sistema de apropriação capitalista. Entende-se melhor porque Marx diz no livro I que "a propriedade privada capitalista [...] é a primeira negação da propriedade privada individual" (MARX, 1996 b, p. 381). 
Assim, a partir do estudo da reprodução ampliada do capital, vê-se em ato, não só o fetichismo do dinheiro (o que vimos ser essencial para a compreensão do Direito em Marx e, acreditamos, no capitalismo); tem-se também o modo pelo qual, mediante o papel que vem adquirir as transações jurídicas, os contratos e os títulos jurídicos, o sistema de apropriação burguês entra em contradição consigo mesmo. A apropriação a partir do tempo de trabalho e da troca equivalente (tratados por Pachukanis a partir do livro I) passa a ceder espaço para o papel proeminente que adquire a propriedade privada burguesa reconhecida juridicamente pelo Estado. E isto, segundo Marx, traz à tona, ao mesmo tempo, a possibilidade de supressão do sistema capitalista de produção (e, assim, da negação da lei do valor) e a possibilidade de sua manutenção, sem que se tenha a "expropriação de poucos usurpadores pela massa do povo" (MARX, 1996 b, p. 381), e, assim, a superação da sociedade capitalista. Esta última, agora, já nega seus próprios pressupostos originários e passa constituir-se como um entrave para que se estabeleça "a propriedade individual sobre o fundamento do conquistado na era capitalista: a cooperação e a propriedade comum da terra e dos meios de produção produzidos pelo próprio trabalho" (MARX, 1996 b, p. 381). As consequências desta última possibilidade são tratadas no livro III por Marx quando ele traz à tona o papel das sociedades por ações e das cooperativas (Cf. MARX, 1986 a, b; SARTORI, 2019 c). Aqui, para os nossos fins, devemos destacar algo essencial: o modo pelo qual o autor de $O$ capital, no livro II, trata da correlação entre capital monetário e produtivo explicita algumas questões importantes sobre o anacronismo do sistema de apropriação capitalista e, em meio a estas, tem-se o Direito colocando-se como um elo essencial no já anacrônico sistema capitalista de apropriação.

No livro II, e nas Teorias do mais-valor ${ }^{44}$, Marx mostra como que o outro lado do crescimento do capital monetário e das mediações entre a produção e o consumo - as quais, por meio da divisão do trabalho geraram ganho de produtividade e desenvolvimento de forças produtivas - é o gigantismo do Estado e uma posição acrítica quanto aos juristas, a igreja e quanto a diversos elementos contra os quais a burguesia se insurgiu anteriormente. Marx diz,

\footnotetext{
${ }^{44}$ Aponta Marx a tendência na sociedade capitalista ao crescimento das camadas intermediárias que se interpõem na produção; inclusive, destaca os juristas em meio a estas camadas: "como os trabalhadores improdutivos políticos. Podia-se admitir que excetuados a horda de criados, os soldados, marinheiros, policiais, funcionários subalternos etc., concubinas, palhaços, malabaristas - esses trabalhadores improdutivos no conjunto teriam melhor nível de cultura que os anteriores trabalhadores improdutivos, e sobretudo que o número de artistas, músicos, advogados, médicos, homens de letras, professores, inventores etc., mal pagos, teria também aumentado. No seio da própria classe produtiva acresceram os intermediários comerciais, e em particular os empregados na construção de máquinas, nas ferrovias, na mineração e escavação; além disso os trabalhadores que na agricultura se dedicam a criar gado, produzem materiais químicos, minerais para adubos etc.” (MARX, 1980, p. 199)
} 
assim, que "a sociedade burguesa passa a produzir, em sua própria forma, tudo que combatera na forma feudal ou absolutista" (MARX, 1980. p. 154). E, desta maneira, o conhecimento que poderia se colocar a serviço do maior desenvolvimento das forças produtivas volta-se contra este na medida em que se tem como efetiva "a dependência das classes ideológicas etc. para com os capitalistas" (MARX, 1980, p. 154) ${ }^{45}$. Deste modo, ao mesmo tempo, ao se analisar o papel que o Direito tem no livro II, percebe-se do modo pelo qual sua função é um sintoma do anacronismo do sistema de apropriação capitalista, mas, ao mesmo tempo, passa longe de trazer qualquer solução a isto; antes, a esfera jurídica tem uma função bastante importante na operacionalização deste sistema de apropriação na medida em que este se coloca como anacrônico. O movimento do Direito expressa, portanto, ao mesmo tempo, a negação da propriedade privada individual, a afirmação da propriedade privada capitalista e a possibilidade - mas não a efetividade - da negação desta última. As referências ao Direito no livro II trazem consigo esta marca, que pode ser relacionada ao aspecto dúplice do capital monetário, que opera - também - por meio das diversas formas jurídicas. Estas formas, assim, operacionalizam figuras econômicas autonomizadas que ganham proeminência na medida em que a produção capitalista (baseada na apropriação do trabalho alheio, e no trabalho abstrato) entra em contradição com a forma de apropriação capitalista, que não parte mais, imediatamente, da necessidade de se apropriar da riqueza por meio do trabalho. A centralidade que adquire o reconhecimento oficial dos títulos de propriedade explicita dois aspectos antagônicos: o anacronismo de um modo de produção baseado no tempo de trabalho socialmente necessário, e a forma pela qual, por meio da titularidade jurídica, a riqueza não é apropriada social, comunitária e racionalmente, mas de modo privado, a partir de uma forma social em que "o

\footnotetext{
${ }^{45}$ Veja-se a passagem completa de Marx: "a economia política no período clássico, do mesmo modo que a própria burguesia no período inicial de autoafirmação, porta-se de maneira severa e crítica com a maquinaria governamental etc. Mais tarde percebe e - como a prática também evidencia - pela experiência apreende que brota de sua própria organização a necessidade da combinação social de todas essas classes, em parte por completo improdutivas. Até onde aqueles 'trabalhadores improdutivos' não criam meios de fruição e, por isso, comprá-los dependa totalmente do modo como o agente da produção quer despender o salário ou o lucro, e até onde, ao contrário, são necessários ou se façam necessários em virtude de doenças (caso dos médicos) ou de fraquezas espirituais (caso dos padres) ou de conflitos entre os interesses privados e os nacionais (caso dos administradores públicos, juristas, policiais, soldados), são vistos por A. Smith, pelo próprio capitalista industrial e pela classe trabalhadora, como falsos custos de produção, que importa reduzir o mais possível, ao mínimo necessário e na base da mais baixa remuneração dos serviços. A sociedade burguesa passa a produzir, em sua própria forma, tudo que combatera na forma feudal ou absolutista. Tarefa principal dos sicofantas dessa sociedade, sobretudo os dos 'níveis mais altos' é portanto, em primeiro lugar, restaurar no plano teórico o segmento meramente parasitário desses 'trabalhadores improdutivos' ou ainda justificar as exigências exageradas da fração para ela indispensável. Proclamou-se, na realidade, a dependência das classes ideológicas etc. para com os capitalistas. (MARX, 1980, p. 154)
} 
poder social torna-se, assim, poder privado da pessoa privada" (MARX, 1996 a, p. 252). O Direito, assim, é um importante elemento na operacionalização da distribuição da riqueza decorrente de uma sociedade em que há uma flagrante contradição entre as forças produtivas e as relações de produção.

Há também um elemento, por assim dizer, ideológico sobre este processo. E ele deve ser trazido à tona. No próprio livro II, tem-se aspectos a serem destacados. Ao tratar da reprodução do capital, e, em especial, da manutenção do capital fixo por parte dos trabalhadores, Marx traz um ponto bastante importante sobre o tema. Diz ele, remetendo ao ponto de vista jurídico burguês:

O capital fixo exige também dispêndio positivo de trabalho para sua manutenção. A maquinaria precisa ser limpa periodicamente. Trata-se aqui de trabalho adicional, sem o qual ela se toma inutilizável; de mera defesa contra influências prejudiciais dos elementos, que são inseparáveis do processo de produção, portanto de manutenção, no sentido literal, da capacidade de operar. O tempo de vida normal do capital fixo se calcula, naturalmente, admitindose que estejam preenchidas as condições em que pode funcionar normalmente durante esse tempo, como se supõe que, se um homem vive em média 30 anos, ele se lave. Não se trata aqui da reposição do trabalho contido na máquina, mas de trabalho adicional contínuo que seu uso torna necessário. Não se trata de trabalho feito pela máquina, mas feito sobre ela, no qual ela não é agente da produção, mas matéria-prima. $\mathrm{O}$ capital investido nesse trabalho, embora não entre no processo de trabalho propriamente dito, ao qual o produto deve sua origem, faz parte do capital fluido. Esse trabalho tem de ser continuamente despendido na produção, seu valor, portanto, continuamente reposto pelo valor do produto. $\mathrm{O}$ capital despendido nele pertence à parte do capital fluído que tem de cobrir os falsos custos gerais e que, mediante um cálculo da média anual, deve se repartir pelo produto-valor. Vimos que na indústria propriamente dita esse trabalho de limpeza é executado gratuitamente pelos trabalhadores nos momentos de descanso, motivo pelo qual o realizam muitas vezes durante o próprio processo de produção, onde se toma a causa da maioria dos acidentes. Esse trabalho não conta no preço do produto. $\mathrm{O}$ consumidor o recebe, nesta medida, gratuitamente. Por outro lado, o capitalista obtém, desse modo, os custos de manutenção de sua máquina de graça. $\mathrm{O}$ trabalhador paga com sua própria pessoa e isso constitui um dos mistérios da autoconservação do capital, os quais constituem de fato um direito do trabalhador sobre a maquinaria e o tornam, mesmo do ponto de vista jurídico burguês, co-proprietário dela. (MARX, 1985, pp. 127-128)

Na passagem, Marx trata de uma questão típica da reprodução capitalista, ligada à conservação da maquinaria e ao modo pelo qual a acumulação de capital se dá com dispêndio de tempo de trabalho tanto para que se preserve o capital constante (c), aqui visto como capital fixo. Aborda, mesmo que de modo pressuposto, também as condições para que se tenha o consumo necessário para a reprodução física e moral da força de trabalho, que compõe o capital variável (v). 
Vê-se, assim, que, segundo o autor, o investimento na produção não se dá só para que ela possa ser incrementada, mas também para que as condições de trabalho (e os próprios meios de produção, cuja titularidade é do capitalista) sejam mantidos. Tratar-se-ia de uma espécie de capital fluído, que irá cobrir aquilo que Marx chama de falsos custos, e que não se conforma como trabalho propriamente produtivo. Marx destaca que isto se dá, em sua época, ao passo que os trabalhadores que operam as máquinas, por vezes, também as limpam e fazem a manutenção delas; e, deste modo, trabalham na própria reprodução dos meios de produção que lhes são estranhos e que se colocam como uma potência estranha à sua atividade. A pessoa do trabalhador, deste modo, é vilipendiada para que a maquinaria seja preservada. O domínio das coisas sobre os homens, trazido no livro I com referência à noção de reificação, aparece aqui, no livro II em ato. No entanto, há de se destacar que, neste processo, tal atividade do trabalhador, do ponto de vista do Direito burguês, faria do trabalhador, em verdade, co-proprietário da maquinaria. E, assim, temos algo de grande relevo para o tema que nos propomos a abordar aqui. Há duas questões importantes na passagem: a primeira delas diz respeito ao modo pelo qual o ponto de vista jurídico burguês de que fala Marx na passagem é, até certo ponto, negado no próprio capitalismo. O segundo aspecto diz respeito à noção de pessoa que figura na passagem em correlação com o Direito.

Não necessariamente o próprio trabalhador que trabalha com determinados meios de produção faz a manutenção destes ${ }^{46}$. Se não fosse este o caso, a manutenção da maquinaria constaria ao empresário como um custo de produção, a ser pago, seja a uma outra empresa, seja a trabalhadores do ramo. No entanto, para o que nos diz respeito neste artigo, nota-se que o fato de os trabalhadores fazerem a manutenção da maquinaria, a limpeza desta, em seus horários de descanso, do ponto de vista do Direito burguês - que liga o trabalho à apropriação, tal qual em Locke, por exemplo ${ }^{47}$-, faz com que eles devessem ser co-proprietários da maquinaria. Neste momento, eles não venderam a sua força de trabalho aos burgueses e, portanto, aquilo produzido não é direito do proprietário do meio de produção. Isto, porém, no modo de produção capitalista,

\footnotetext{
${ }^{46} \mathrm{Na}$ continuação da passagem, diz Marx que “em diversos ramos da produção, porém, em que a maquinaria tem de ser retirada do processo de produção para sua limpeza e, por isso, esta não pode ser feita no meio-tempo, como, por exemplo, no caso das locomotivas, esse trabalho de manutenção figura entre os custos correntes, portanto como elemento do capital fluido. Depois de funcionar no máximo 3 dias, uma locomotiva tem de ser levada à oficina para limpeza; a caldeira tem de esfriar primeiro para não se estragar com a lavagem." (MARX, 1985, pp. 127-128)

${ }^{47}$ Para Marx, neste ponto, tem-se a posição da economia política: “a concepção de Locke é da maior importância porque é a expressão clássica das ideias jurídicas da sociedade burguesa em oposição à feudal, e além disso sua filosofia serviu de base a todas as ideias desenvolvidas por toda a economia inglesa posterior.” (MARX,1980, p. 356)
} 
não poderia ser colocado em prática; e, assim, a posição segundo a qual o produto do trabalho é daquele que produz entra em contradição com o modo pelo qual a riqueza vem a ser dividida em meio ao desenvolvimento do capitalismo. Se em um primeiro momento, na proeminência do capital industrial nascente, o burguês realizava o trabalho de supervisão, isto não se dá mais depois de determinado momento. Um assalariado passa a realizar tal trabalho. (Cf. MARX, 1986, a, b; SARTORI, 2019 c) Tem-se também que, com o aumento da função do capital monetário no processo de circulação do capital, bem como no processo global de produção, não são só os agentes da produção que se apropriam da riqueza social, mas também, entre outros, os agentes da circulação ${ }^{48}$. A concepção burguesa de Direito precisa mudar substancialmente. Ela, depois de determinado momento do desenvolvimento capitalista, traz, não mais a apropriação por meio do trabalho como algo essencial, mas os direitos à apropriação que decorrem da titularidade jurídica.

Marx, assim, de certo modo, traz um tema central para a compreensão do Direito: a centralidade da propriedade privada nesta esfera do ser social. Acreditamos que, com uma leitura atenta do livro II, tal questão possa ser esclarecida, ultrapassando em muito uma crítica ao Direito que - em grande parte acertadamente - traz consigo a correlação entre mercadoria e Direito. Para que se perceba, tanto do modo pelo qual a ideologia jurídica se desenvolve, quanto da maneira pela qual ela expressa relações de produção anacrônicas, há de se analisar as contradições que marcam as formas e as figuras econômicas do modo de produção capitalista. Somente então, pode-se enxergar como que se coloca o Direito, bem como seu movimento, por assim dizer interno.

Ao analisar o livro II, porém, há de se notar ainda algo mais: Marx, ao mesmo tempo que trata do Direito, traz à tona a noção de pessoa. E, na passagem, resta claro: não é porque o autor de $O$ capital traz em conjunto as duas noções, que se tem uma crítica à categoria sujeito de direito, central na crítica pachukaniana, como central. O movimento do sujeito automático do capital se impõe sobre a individualidade dos trabalhadores de modo que "o trabalhador paga com sua própria pessoa" (MARX, 1985, pp. 127) para que a maquinaria possa se manter. Novamente, tal qual no livro I (Cf. SARTORI, 2019 a) o que se tem não é tanto uma crítica à noção - importante para os juristas - de sujeito de direito, mas a exposição de como o processo produtivo capitalista se impõe aos trabalhadores trazendo, em ato, a reificação de sua atividade,

\footnotetext{
${ }^{48}$ Aqui não podemos falar de outras camadas e classes sociais. No entanto, principalmente no livro III (1986 a, b) e nas Teorias do mais-valor (1980) Marx dá importantes apontamentos sobre o tema.
} 
que é mediada pelas formas econômicas tratadas em $O$ capital. O trabalhador paga com sua pessoa dispendendo energia vital para que as máquinas se preservem e, assim, o processo de extração de mais-valor possa continuar. Deparamo-nos, portanto, com o entrelaçamento de formas econômicas - mercadoria, dinheiro, capital, mas também, neste caso, uma forma antediluviana de manutenção da maquinaria -, e não com um processo em que o Direito seja o essencial. Certamente, também neste caso, de um modo ou doutro, opera-se por meio do Direito na superfície da sociedade; porém, o movimento do processo produtivo se dá por meio do entrelaçamento contraditório de formas e figuras econômicas. Ou seja, é preciso que se compreenda esta dialética peculiar, bem como o papel que cumprem o fetichismo da mercadoria e do dinheiro nela; o importante passa longe de ser o fetichismo jurídico. Embora uma crítica ao Direito seja essencial, ela somente abre as portas para que seja possível a compreensão do processo econômico que determina o conteúdo das formas jurídicas.

Também aqui, não se pode confundir o reconhecimento jurídico com os fatos econômicos. Por mais que os últimos não possam se colocar como se colocam sem a mediação do Direito, eles não "são" jurídicos. As trocas mercantis estão situadas na esfera da circulação e em meio ao processo de circulação de capital, tendo consigo o desenvolvimento do capital monetário como suposto. Tem-se também o entrelaçamento entre o capital produtivo e o improdutivo. Esta esfera, por sua vez, depende da proporção entre o capital constante (c) e o variável (v), bem como entre o departamento de produção de bens de consumo (I) e de bens de produção (II). Os contratos, o direito à apropriação da riqueza social, as transações jurídicas, bem como as expectativas jurídicas só podem se colocar sob o solo destas relações de produção. Exercem, portanto, um papel de enorme importância no encaminhamento destas relações, mas, como simples formas, não determinam seu conteúdo. Ao analisar o livro II, vê-se isto em ato. Nota-se também que o elemento dúplice do capital monetário precisa de uma representação por meio de títulos jurídicos. E, deste modo, também aqui, o Direito cumpre um papel de enorme relevo, mas, ao mesmo tempo, tem uma dependência diante do solo da produção. E, como vimos, tal aspecto pode ser importante, inclusive, para que se pense o modo pelo qual as crises do sistema capitalista de produção perpassam - embora não de modo essencial - por um elemento jurídico. O livro II, portanto, traz um tema essencial ao marxismo, aquele das crises do modo de produção capitalista.

Por isso também, o tratamento deste livro de $O$ capital pode ser de grande relevo. $\mathrm{O}$ caráter contraditório da sociedade capitalista, bem como o modo pelo qual ela traz consigo a 
negação potencial de elementos essenciais dela aparece em ato ao se analisar o processo de circulação. No que diz respeito ao Direito, abre-se um flanco bastante importante nos estudos da obra de Marx, do modo de produção capitalista e, acreditamos, da própria crítica ao Direito: já em $O$ capital, há apontamentos importantes que remetem às razões e aos fundamentos da centralidade da propriedade privada, da titularidade jurídica, das transações jurídicas e também dos contratos na jurisprudência. Ao tratar do livro II, acreditamos, é possível avançar substancialmente nos estudos críticos sobre o Direito, indo muito além daquilo tratado classicamente por Pachukanis em seu importante livro. Em meio à reprodução e à acumulação de capital aparecem temas essenciais, tanto ao estudo de Marx, quanto da crítica marxista ao Direito e da compreensão crítica do modo de produção capitalista.

\section{Bibliografia:}

ALMEIDA SALES Jr, José Roberto. O Direito como freio irracional na formação do capitalismo na Prússia revolucionária: a analítica marxiana do território do Direito na Nova Gazeta Renana. Dissertação de mestrado. Juiz de Fora: Pós Graduação em Direito, UFJF, 2018. ALTHUSSER, Louis. A favor de Marx. Trad. Dirceu Lindoso. São Paulo: Zahar, 1979.

. A querela sobre o humanismo (I). In: Crítica Marxista n. 9. São Paulo: Xamã, 1999. . A querela sobre o humanismo (II). In: Crítica Marxista n. 12. Rio de Janeiro, 2002. ALVES, Antônio José Lopes. Marx e a analítica de O capital. Saarbrucken: Novas edições acadêmicas, 2013.

CASALINO, Vinícius. Direito e mercadoria. São Paulo: Dobra editorial, 2011.

UERJ, 2019.

. O capital como sujeito de direito. In: Direito e práxis, V. 10, n. 4. Rio de Janeiro:

CHASIN, José. Marx: Estatuto Ontológico e Resolução Metodológica. São Paulo: Boitempo, 2009.

COTRIM, Vera. Trabalho produtivo em Karl Marx: novas e velhas questões. São Paulo: Alameda, 2013.

ENGELS, Friedrich; KAUTSKY, Karl. O socialismo jurídico. Trad. Márcio Naves e Lívia Cotrim. São Paulo: Boitempo, 2012, p. 17-18.

FLORÊNCIO DE MELO, Carlos. O lugar dos manuscritos etnológicos na obra de Karl Marx. Dissertação de mestrado. Belo Horizonte: UFMG, Faculdade de Direito, 2019.

GRESPAN, Jorge. As formas da mais-valia: concorrência e distribuição no livro III de O capital. In: Crítica marxista 33. São Paulo: Unesp, 2011 (pp.9-30)

. Marx e a crítica ao modo de representação capitalista. São Paulo: Boitempo, 2019.

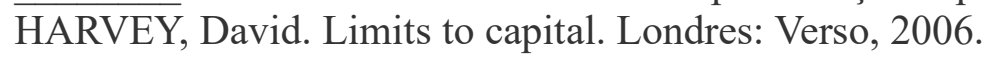

. Para entender O capital (livros II, III). Trad. Rubens Enderle. São Paulo, 2014.

KASHIURA JR., Celso Naoto. Crítica da igualdade jurídica. São Paulo: Quartier Latin, 2009. . Sujeito de direito e capitalismo. São Paulo: Expressão Popular, 2014.

LUKÁCS, György. El Asalto a la Razón. Trad. Wenceslau Roces. México: Fondo de Cultura Econômica, 1959.

. Ontologia do ser social II. Trad. Nélio Schneider. São Paulo: Boitempo, 2013.

LUXEMBURGO, Rosa. A acumulação de capital. Trad. Marijane Vieira Lisboa. São Paulo: 
Nova abril cultural, 1985.

MACHADO, Gustavo. Sobre a possibilidade de uma revolução russa nos escritos de Marx. In: Verinotio: Revista Online de Filosofia e Ciências Humanas, n. 23, v. 1. Belo Horizonte: $2017<\mathrm{http} / / /$ www.verinotio.org/conteudo/0.913956650452648.pdf $>$ Acesso em 24/01/2017. MARX, Karl. MARX, Karl. Glosas marginais ao Manual de economia política de Adolph Wagner. Trad. Luiz Philipe De Caux. In: Verinotio: revista on-line de filosofia e ciências humanas, V. 23, N. 2. Rio das Ostras: UFF, 2017.

. Grundrisse. Trad. Mario Duayer. São Paulo: Boitempo, 2011.

. Los apuntes etnológicos de Karl Marx. (KRADER, Lawrance Org.). Madrid: Pablo

Iglesias Editorial, 1988.

. Miséria da Filosofia. Trad. José Carlos Orsi Morel. São Paulo: Ícone, 2004.

. O capital, livro I, tomo I. Trad. Trad. Regis Barbosa e Flávio R. Kothe São Paulo:

Nova Cultural, 1996 a.

. O capital, livro I, tomo II. Trad. Trad. Regis Barbosa e Flávio R. Kothe São Paulo:

Nova Cultural, 1996 b.

1985.

. O capital, livro II. Trad. Regis Barbosa e Flávio R. Kothe São Paulo: Nova Cultural,

. O capital, livro III, tomo I. Trad. Trad. Regis Barbosa e Flávio R. Kothe São Paulo:

Nova Cultural, 1986 a.

. O capital, livro III, tomo II. Trad. Trad. Regis Barbosa e Flávio R. Kothe São Paulo: Nova Cultural, 1986 b.

. Para uma crítica da economia política. Trad. Edgar Malagodi e Leandro Konder. São Paulo: Abril Cultural, 1982

1980.

. Teorias da mais-valia. Trad. Reginaldo Sant'Anna. São Paulo: Civilização brasileira,

MARX, Karl; ENGELS, Friedrich. A luta de classes na Rússia. Trad. Nélio Schneider. São Paulo: Boitempo, 2013.

MASCARO, Alysson Leandro Barbate. Crise e golpe. São Paulo: Boitempo, 2018.

. Filosofia do direito. São Paulo: Atlas, 2012.

. Utopia e Direito. São Paulo: Quartier Latin, 2008.

MEDRADO, Nayara. Crime, sujeito e revolução: a questão penal em Marx. Dissertação de mestrado. Belo Horizonte: UFMG, Faculdade de Direito, 2018.

NAVES, Márcio Bilharinho. Marxismo e Direito: um estudo sobre Pachukanis. Boitempo: São Paulo, 2000.

. A questão do direito em Marx. São Paulo: Expressão Popular, 2014.

PACHUKANIS, E. P. Teoria geral do Direito e o marxismo. Trad. Paula Vaz de Almeida. São Paulo: Boitempo, 2017.

PAÇO CUNHA, Elcemir. Considerações sobre a determinação da forma jurídica a partir da mercadoria. Crítica do Direito, n. 64. São Paulo: Mackenzie, 2014.

. Do fetiche da mercadoria ao "fetiche do Direito" e de volta. In: Verinotio: Revista

Online de Filosofia e Ciências Humanas, n. 19. Belo Horizonte: 2015. (Disponível em www.verinotio.org)

PALU, Marco Aurélio. Estado, democracia e gênero humano: a crítica de 1843 e a fundação do pensamento marxiano. Dissertação de mestrado. Belo Horizonte: UFMG, Faculdade de Direito, 2019.

PEREIRA NETO, Murilo. A posição de Marx quanto ao Direito nos escritos de 1837-1843.

Dissertação de mestrado. Belo Horizonte: UFMG, Faculdade de Direito, 2018.

PARREIRA, Lucas. Entre flexas e martelos: Marx como leitor de Henry Morgan (dissertação 
de mestrado). Belo Horizonte: UFMG, 2019.

REICHELT, Helmut. Sobre a estrutura lógica do conceito de capital em Marx. Trad. Nélio Schneider. Campinas: Unicamp, 2013.

ROSDOLSKY, Roman. Gênese e estrutura de O capital. Trad. César Benjamin. Rio de Janeiro: Contraponto, 2001.

RUBIN, Isaac Illich. Teoria marxista do valor. Trad. José Bonifácio de S. Amaral Filho. São Paulo: Polis, 1987.

SARTORI, Vitor Bartoletti. Acerca da categoria de "pessoa" e de sua relação com o processo de reificação em "O capital" de Karl Marx: um debate com Pachukanis. In: Cadernos de ética e filosofia política, V 1, N 34. São Paulo: USP, 2019 a

. Apontamentos sobre justiça em Marx. Nomos, V. 37, n.1. Fortaleza: UFC, 2017 b.

Horizonte: 2014.

. De Hegel a Marx: da inflexão ontológica à antítese direta. In: Kriterion n.130. Belo

Fetichismo, transações jurídicas, socialismo vulgar e capital portador de juros: o livro III de O capital diante do papel ativo do Direito. Revista da Sociedade Brasileira de Economia política. Niterói: UFF, 2019 c.

. Marx diante da revolução social na Rússia do século XIX. In: Verinotio: Revista

Online de Filosofia e Ciências Humanas, n. 23, v. 1. Belo Horizonte: 2017 a $<$ http://www.verinotio.org/conteudo/0.4443315485905218.pdf $>$ Acesso em 05/01/2017.

. Sociedades capitalistas tardias, o livro III de O capital e a dialética entre trabalho e as figuras econômicas concretas. In: Revista de estudos organizacionais, V. 6, N.1. Rio de Janeiro: UFF, $2019 \mathrm{~b}$.

. Trabalho, riqueza e natureza humana: Marx e a crítica ao modo de produção capitalista. In: Sapere Aude. Belo Horizonte, PUC Minas, 2018.

. Teoria geral do Direito e o marxismo como crítica marxista ao Direito. In:

Verinotio: Revista Online de Filosofia e Ciências Humanas, n. 19. Belo Horizonte: 2015. (Disponível em $<$ www.verinotio.org $>$ )

SILVA, Lucas Almeida. O movimento do Direito nos textos econômicos de Karl Marx. Dissertação de mestrado. Juiz de Fora: UFJF, Faculdade de Direito, 2018.

SOARES, Moisés Alves. Direito e Alienação nos Grundrisse de Karl Marx. Florianópolis, 2011. 213p. Dissertação (Mestrado) - Universidade Federal de Santa Catarina, Centro de Ciências Jurídicas, Programa de Pós-Graduação em Direito, Florianópolis, 2011. 